NBER WORKING PAPER SERIES

\title{
PARENTAL EDUCATION AND CHILD HEALTH: EVIDENCE FROM A NATURAL EXPERIMENT IN TAIWAN
}

\author{
Shin-Yi Chou \\ Jin-Tan Liu \\ Michael Grossman \\ Theodore J. Joyce \\ Working Paper 13466 \\ http://www.nber.org/papers/w13466 \\ NATIONAL BUREAU OF ECONOMIC RESEARCH \\ 1050 Massachusetts Avenue \\ Cambridge, MA 02138 \\ October 2007
}

This paper was presented at the Sixth World Congress of the International Health Economics Association in Copenhagen, Denmark, July 9-11, 2007. Research for the paper was supported by grant number 5 R01 HD045603 from the National Institute of Child Health and Human Development to the National Bureau of Economic Research. The paper has had a long gestation period due to problems encountered in using Taiwanese birth and infant death certificates and in accurately measuring new junior high school openings. Preliminary versions of the paper with empirical results that turned out to be incorrect after inconsistencies in the data were uncovered and resolved were presented at the 2004 Annual Meeting of the Population Association of America, the Fourth World Congress of the International Health Economics Association, the 2005 NIA/NICHD Intergenerational Research Workshop and at seminars at Harvard University, Cornell University, the State University of New York at Buffalo, National Taiwan University, the University of South Florida, and the University of Medicine and Dentistry of New Jersey School of Public Health. We wish to thank the participants in those forums for helpful comments and suggestions. We also wish to thank Silvie Colman, Ryan Conrad, Danielle Ferry, and Wehn-Jyuan Tsai for research assistance. The views expressed herein are those of the author(s) and do not necessarily reflect the views of the National Bureau of Economic Research or the National Institute of Child Health and Human Development.

(C) 2007 by Shin-Yi Chou, Jin-Tan Liu, Michael Grossman, and Theodore J. Joyce. All rights reserved. Short sections of text, not to exceed two paragraphs, may be quoted without explicit permission provided that full credit, including $\odot$ notice, is given to the source. 
Parental Education and Child Health: Evidence from a Natural Experiment in Taiwan Shin-Yi Chou, Jin-Tan Liu, Michael Grossman, and Theodore J. Joyce NBER Working Paper No. 13466

October 2007

JEL No. I10,I20

\begin{abstract}
$\underline{\text { ABSTRACT }}$
This paper exploits a natural experiment to estimate the causal impact of parental education on child health in Taiwan. In 1968, the Taiwanese government extended compulsory education from six to nine years. From that year through 1973, the government opened 254 new junior high schools, an 80 percent increase, at a differential rate among regions. We form treatment and control groups of women or men who were age 12 or under on the one hand and between the ages of 13 and 20 or 25 on the other hand in 1968. Within each region, we exploit variations across cohorts in new junior high school openings to construct an instrument for schooling. We employ this instrument to estimate the causal effects of mother's or father's schooling on the incidence of low birthweight and mortality of infants born to women in the treatment and control groups or the wives of men in these groups in the period from 1978 through 1999. Parents' schooling, especially mother's schooling, does indeed cause favorable infant health outcomes. The increase in schooling associated with the reform saved almost 1 infant life in 1,000 live births, resulting in a decline in infant mortality of approximately 11 percent.

Shin-Yi Chou

Department of Economics

College of Business and Economics

Lehigh University

621 Taylor Street

Bethlehem, PA 18015-3117

and NBER

syc2@lehigh.edu

Jin-Tan Liu

Department of Economics

National Taiwan University

21 Hsu-Chow Road

Taipei (100), TAIWAN

and NBER

liujt@ccms.ntu.edu.tw

Michael Grossman

Ph.D. Program in Economics

City University of New York Graduate Center

365 Fifth Avenue, 5th Floor

New York, NY 10016-4309

and NBER

mgrossman@gc.cuny.edu

Theodore J. Joyce

Baruch College and NBER

365 Fifth Avenue, 5th Floor

New York, NY 10016-4309

and NBER

Ted_Joyce@baruch.cuny.edu
\end{abstract}


"The one social factor that researchers agree is consistently linked to longer lives in every country where it has been studied is education. It is more important than race; it obliterates any effects of income." Gina Kolata, "A Surprising Secret to Long Life: Stay in School,” New York Times, January 3, 2007, p. 1.

\section{Introduction}

This paper is a contribution to the literature on the relationship between years of formal schooling completed and good health. In particular we investigate whether the positive relationship between these two variables implies causality from the former to the latter. As the quotation from Kolata indicates, there is a large literature, reviewed in detail by Kaestner and Grossman (1997) and Grossman $(2000,2006)$, that shows that an individual's own schooling is the most important correlate of his or her health and that parents' schooling, especially mother's schooling, is the most important correlate of child health. This finding emerges whether health levels are measured by mortality rates, morbidity rates, self-evaluation of health status, or physiological indicators of health, and whether the units of observation are individuals or groups. Improvements in child health are widely accepted public policy goals in developing and developed countries. The positive correlation between mother's schooling and child health in numerous studies was one factor behind the World Bank's campaign in the 1990s to encourage increases in maternal education in developing countries (World Bank 1993). In a 2002 issue of Health Affairs devoted primarily to the nonmedical determinants of health, Deaton (2002) argues that policies to increase education in the U.S. and to increase income in developing countries are very likely to have larger payoffs in terms of health than those that focus on health care, even if inequalities in health rise. The same proposition with regard to the U.S. can be found in a much earlier study by Auster, Leveson, and Sarachek (1969). Since more education typically leads to higher income, policies to increase the former appear to have large returns for more than one 
generation throughout the world.

Efforts to improve the health of an individual by increasing the amount of formal schooling that he or she acquires or that try to improve child health by raising maternal schooling assume that the schooling effects reported in the literature are causal. A number of investigators have argued, however, that reverse causality from health to schooling or omitted "third variables" may cause schooling and health to vary in the same direction. Governments can employ a variety of policies to raise the educational levels of their citizens. These include compulsory schooling laws, new school construction, and targeted subsidies to parents and students. If proponents of the third-variable hypothesis are correct or if health causes schooling, evaluations of these policies should not be based on studies that relate adult health or child health to actual measures of schooling because these measures may be correlated with unmeasured determinants of the outcomes at issue.

In this paper we propose to use techniques that correct for biases due to the endogeneity of schooling to evaluate the effects of a policy initiative that radically altered the school system in Taiwan and led to an increase in the amount of formal schooling acquired by the citizens of that country during a period of very rapid economic growth. In 1968 Taiwan extended compulsory schooling from six years to nine years. In the period from that year through 1973, many new junior high schools were opened at a differential rate among regions of the country. We form treatment and control groups of women or men who were age 12 or under on the one hand and between the ages of 13 and 20 or 25 on the other hand in 1968. Within each region, we exploit variations across cohorts in new junior high school openings to construct an instrument for schooling. We employ this instrument to estimate the causal effects of mother's or father's schooling on the incidence of low birthweight and mortality of infants born to women 
in the treatment and control groups or the wives of men in these groups in the period from 1978 through 1999.

The paper proceeds as follows. Section II outlines a conceptual framework, followed by a review of the related literature. Second III provides some background on education reform in 1968 in Taiwan and indicates how we exploit aspects of the reform to construct instruments for parents' schooling in empirical estimates of the impacts of that variable on child health. Section IV describes the empirical strategy and empirical specification. Section V reports the estimation results and Section VI concludes.

\section{Analytical Framework and Review of Literature}

Models that generate two-way causality between schooling and good health and that introduce third-variables that cause both outcomes to vary in the same direction are discussed in detail by Grossman (2006). Consequently, they will be outlined briefly here. Causality from own schooling to own health or from parents' schooling to child health results when the more educated are more efficient producers of these outcomes or when education changes tastes in favor of health. The efficiency effect can take two forms. Productive efficiency pertains to a situation in which the more educated obtain a larger health output from given amounts of endogenous (choice) inputs. Allocative efficiency pertains to a situation in which schooling increases information about the true effects of the inputs on health. For example, the more educated may have more knowledge about the harmful effects of cigarette smoking or about what constitutes an appropriate diet.

Endogenous taste models also generate causality from schooling to health. For example, Becker and Mulligan (1997) show that the more educated have greater incentives to make 
investments that make them or their children more future oriented. The resulting reduction in the rate of time preference for the present raises optimal investment in health.

Now consider causality from health to schooling. In the case of these outcomes for the same person, healthier individuals have longer life expectancies and hence greater payoffs to schooling investments since the number of periods over which returns accrue is larger. Moreover, students in poor health are almost certain to miss more days of school due to illness than their healthy peers and may also learn less while in school. Both factors suggest negative effects of poor health in childhood on school achievement and ultimately on years of formal schooling completed. In the case of child health, parents who demand higher levels of this outcome may obtain more schooling because it is a mechanism to achieve this goal.

Since health and schooling are both endogenous, unobserved third variables may cause both of these outcomes to vary in the same direction. The third-variable hypothesis has received the most amount of attention in the literature because it is related to the hypothesis that the positive effect of schooling on earnings, explored in detail by Mincer (1974) and in hundreds of studies since his seminal work (see Card 1999, 2001 for reviews of these studies), is biased upward by the omission of ability. For example, Fuchs (1982) identifies time preference as the third variable. He argues that persons who are more future oriented (who have a high degree of time preference for the future or discount it at a modest rate) attend school for longer periods of time and make larger investments in their own health and in the health of their children. Thus, the effects of schooling on these outcomes are biased if one fails to control for time preference.

The forces just discussed can be summarized in the following two-equation structural model:

$$
\mathrm{S}=\mathrm{S}\left(\mathrm{P}_{\mathrm{S}}, \mathrm{H}, \mathrm{U}\right)
$$




$$
\mathrm{H}=\mathrm{H}\left(\mathrm{P}_{\mathrm{H}}, \mathrm{S}, \mathrm{U}\right) \text {. }
$$

Here $\mathrm{S}$ and $\mathrm{H}$ are positive correlates of completed schooling and health, $\mathrm{P}_{\mathrm{S}}$ is the price of schooling (or the prices of a vector of schooling inputs), $\mathrm{P}_{\mathrm{H}}$ is the price of health (or the prices of a vector of health inputs), and $\mathrm{U}$ is an unobserved third variable. The prices are uncorrelated with U. Solving equations (1) and (2) simultaneously, one obtains the reduced form schooling equation and health equations:

$$
\begin{aligned}
& \mathrm{S}=\mathrm{S}\left(\mathrm{P}_{\mathrm{S}}, \mathrm{P}_{\mathrm{H}}, \mathrm{U}\right) . \\
& \mathrm{H}=\mathrm{H}\left(\mathrm{P}_{\mathrm{S}}, \mathrm{P}_{\mathrm{H}}, \mathrm{U}\right) .
\end{aligned}
$$

Our aim is to estimate equations (2), (3), and (4). We have no direct measures of the prices of health inputs and assume either that they are not correlated with $\mathrm{P}_{\mathrm{S}}$ or that they are captured by county and year indicators (see Section IV for more details). The application of ordinary least squares to equation (2) produces inconsistent coefficient estimates if $\mathrm{S}$ and $\mathrm{U}$ are correlated. Hence, we employ the program intensity variable described in Section II (a measure of $\mathrm{P}_{\mathrm{S}}$ ) as an instrument for schooling in a two-stage least squares estimation of equation (2). ${ }^{1}$

Our research strategy is related to that in a growing literature that employs instrumental variables techniques (IV) to estimate the causal impact of schooling on health. The earliest studies to employ these techniques are by Berger and Leigh (1989), Sander (1995a, 1995b), and Leigh and Dhir (1997). All four studies employ U.S. data and pertain to adults. In almost all cases the IV coefficients are at least as large in absolute value as the ordinary least squares coefficients. These findings point to causal impacts of schooling on health. This conclusion

\footnotetext{
${ }^{1}$ Note that we do not attempt to distinguish between the productive and allocative efficiency effects of education. In addition, we do not attempt to test the efficiency hypothesis against the alternative hypothesis that education causes health because it is a determinant of time preference. Note also that in the Becker-Mulligan (1997) model, schooling might have no effect on health with an endogenous measure of time preference held constant, but schooling might have a very important indirect or reduced form impact that operates through time preference. Even with an adequate measure of time preference, estimation of their model would be difficult if one wanted to allow that measure and schooling to be endogenous and to allow schooling to enter the structural health equation.
} 
should be interpreted with caution because some of the instruments employed (parents' schooling, parents' income, and cognitive test scores) may be correlated with omitted third variables.

Very recent work by Lleras-Muney (2005), Adams (2002), Arendt (2005, forthcoming), Spasojevic (2003), Oreopoulos (2006), de Walque (2007), Grimard and Parent (2007), Cipollone, Radicchia, and Rosolia (2007), Arkes (2004), and Kenkel, Lillard, and Mathios (2006) address the schooling-health relationship by using compulsory education laws, exemption from military service, unemployment rates during a person's teenage years, and requirements for high school completion and for the receipt of a General Educational Development High School Equivalency Diploma (GED) to obtain consistent estimates of the effect of schooling on adult health or on cigarette smoking--a key determinant of many adverse health outcomes. These variables, some of which result from quasi-natural experiments, are assumed to be correlated with schooling but uncorrelated with time preference and other third variables. Hence, they serve as instruments for schooling in the estimation of health equations by two-stage least squares and its variants. These eleven second-generation studies improve on the four firstgeneration ones by employing instruments that are more likely to be uncorrelated with omitted third variables. Like the earlier studies, however, they conclude that the IV effects of schooling on health are at least as large as the OLS effects.

The IV studies just reviewed examine the effects of the amount of schooling an individual has completed on his or her health as an adult. There are only three corresponding IV studies that consider the effects of parents' schooling on child health. Currie and Moretti (2003) examine the relationship between maternal education and birthweight among U.S. white women with data from individual birth certificates from the Vital Statistics Natality files for 1970 to 
2000. They use information on college openings between 1940 and 1990 to construct an availability measure of college in a woman's 17th year as an instrument for schooling. They find that the negative effect of maternal schooling on the incidence of low birthweight increases in absolute value when it is estimated by instrumental variables. They also find that the negative IV coefficient of maternal schooling in an equation for the probability of smoking during pregnancy exceeds the corresponding OLS coefficient in absolute value. Since it is well known that prenatal smoking is the most important modifiable risk factor for poor pregnancy outcomes in the United States, they identify a very plausible mechanism via which more schooling causes better birth outcomes. Their results suggest that the increase in maternal education between the 1950s and the 1980s accounts for 12 percent of the 6 percentage point decline in the incidence of low birthweight in that period.

Breierova and Duflo (2004) capitalize on a primary school construction program in Indonesia between 1973 and 1978. In that period 61,000 primary schools were constructed. Program intensity, measured by the number of new schools constructed per primary-school age child in 1971, varied considerably across the country's 281 districts. In a study of the effects of schooling on earnings, Duflo (2001) shows that average educational attainment rose more rapidly in districts where program intensity was greater. She also argues that the program had a bigger effect for children who entered school later in the 1970s and no effect for children who entered school before 1974. Therefore, she uses the interaction between year of birth and program intensity as an instrument for schooling for male wage earners in the 1995 intercensal survey of Indonesia who were between the ages of 2 and 24 in 1974. This instrument turns out to be an excellent predictor of schooling.

Breierova and Duflo (2004) use the instrument just described to estimate the effects of 
mother's and father's education on child mortality in the same survey employed by Duflo. They employ fertility and infant mortality histories of approximately 120,000 women between the ages of 23 and 50 in 1995. They find that mother's and father's schooling have about the same negative effects on infant mortality. Some, but not all, of the IV coefficients exceed the corresponding OLS coefficients. The authors treat their results as very preliminary.

McCrary and Royer (2006) use age-at-school entry policies to identify the effect of mother's schooling on the probability of a low-birthweight birth and the probability of an infant death for all births in Texas in the years 1989-2001 and on the probability of a low-birthweight birth for all births in California in 1989-2002. When combined with the effects of compulsory schooling laws on education, school entry age laws suggest that some children born one day after the school entry cutoff will obtain less schooling than comparable children born one day earlier. McCrary and Royer observe this effect for maternal education. They find little evidence, however, that the laws affect infant health outcomes, either in the reduced form or in TSLS with the law combined with the mother's exact date of birth used to form an instrument for schooling. They caution that their results may be heavily influenced by the experience of women from low socioeconomic backgrounds, since other researchers have shown that the parents of these women are more likely to comply with school entry policies.

In summary, the majority of the studies reviewed conclude that schooling causes health and that the IV effects are at least as large as the TSLS effects. Only three of these studies, however, deal with children's health, and only the one by Breierova and Duflo (2004) deals with a developing country. Unlike that study, we employ objective measures of infant health from birth certificates and from merging these certificates with infant death certificates. This is in contrast to Breierova and Duflo who rely on women's reports of deaths of their infants. These 
reports are likely to contain errors.

\section{1968 Education Reform in Taiwan and Construction of Instrument}

In 1968, the Taiwan government extended compulsory education from six to nine years, which required all school-age children (between 6 and 15) to attend elementary school for six years and junior high school for three years. To accommodate the expected increase in enrollment in junior high schools, the government opened 150 new junior high schools, an increase of almost 50 percent, at the beginning of the school year 1968-69 (September 1, 1968). This education reform created the largest expansion in junior high school construction and student enrollment in Taiwan's history (Tsai 2007a, 2007b and the sources listed in Table 1).

Primary school education in Taiwan was nearly universal by the mid-1960s, but approximately one-half of primary school graduates did not obtain additional education because enrollment in public junior high school was restricted by a competitive national examination and by the limited number of junior high schools, especially in rural areas. The national examination was so difficult that parents had to enroll their primary school children in costly after-school tutoring classes if they wanted their children to be admitted to a nominally free public junior high school (Spohr 2003). There were a very small number of private junior high schools, but their tuition amounted to approximately one percent of per capita gross national product (Spohr 2003). The 1968 reform abolished the junior high school entrance examination and made it possible for all primary school graduates to continue their education. Children who had previously ended their education after primary school also were allowed to continue their education as long as they were under the age of 15 in 1968 but were unlikely to do so, as we show in Section IV.

The sizable new junior high school openings in 1968 increased the number of these 
schools from 0.3 schools per thousand children ages 12 through 14 in the school year 1967-1968 to 0.4 schools per thousand children in that age range in the school year 1968-1969 (see Table 1 for sources). ${ }^{2}$ The immediate impact was to increase the percentage of primary school graduates who entered junior high school from 62 percent in 1967 to 75 percent in 1968 (see Figure 1). By 1973, an additional 104 public junior high schools had opened, increasing the total number of these schools from 311 in 1967 to 565 in 1973 (0.5 per thousand children ages 12-14). The junior high school entry percentage rose to 84 percent in the same year. Hence, the number of junior high schools almost doubled in a six-year period, the number per thousand children ages 12 through 14 rose by almost 70 percent, and the junior high school entry percentage grew by 35 percent. After 1973, the government's six-year plan to implement the 1968 legislation ended. The growth in junior high schools slowed, with additional openings resulting mainly from population growth.

A notable aspect of the school construction program was that its intensity varied across regions of Taiwan. Table 1 contains the number of new junior high schools that opened in 1968 per thousand children between the ages of 12 and 14 in that year in each of the 21 cities or counties of Taiwan. ${ }^{3}$ The table also contains the cumulative number of new junior high schools in each of the years 1969 through 1973 per thousand children between the ages of 12 and 14 in that year. In 1968, program intensity varied from 0.02 in Kaohsiung City and Kaohsiung County to 0.53 in Penghu County. By 1973, intensity varied from 0.07 in Changhua County to 0.91 in Penghu County.

\footnotetext{
${ }^{2}$ Hereafter school year $t$ denotes the school year that starts in September of year $t$ and ends in June of year $t+1$.

${ }^{3}$ In Taiwan large cities are separate local entities. Hence Taipei County pertains to the region outside of Taipei City. Unlike Clark and Hsieh (2000), we present separate program intensity data for Taipei City, Kaohsiung City, Taichung City, and Tainan City. This is appropriate because children who reside in Kaohsiung City, for example, do not attend school in the part of Kaohsiung County that is outside the city.
} 
Hence, the nine-year compulsory schooling legislation provides a "natural experiment" to evaluate the impacts of parents' schooling on the health of their children. In particular, those over the age of 12 on September 1, 1968 when the school year began were unlikely to be affected by school reform and constitute a control group. On the other hand, those 12 years of age and under on September 1,1968 were very likely to have been affected by school reform and constitute a treatment group. ${ }^{4}$ Moreover, the effects of school reform on the number of years of formal schooling completed in the treatment group should be larger the larger is the program intensity measure in city or county of birth. (Hereafter the term county refers to city or county of birth.) Clark and Hsieh (2000) present strong evidence in support of this proposition for men in their study of the impacts of schooling on earnings in Taiwan, and we present similar evidence for women in Section IV.

We employ the products of cohort indicators and the program intensity measure in Table 1 as instruments for schooling. Greater intensity among younger cohorts should lead to more schooling but should be uncorrelated with unmeasured determinants of the well-being of the offspring of these cohorts. Unlike Clark and Hsieh (2000) who are forced to predict schooling based on county of current residence of males between the ages of 30 and 50 in the years from 1990 through 1997, we have information on county of birth. Based on our computations from the Taiwan Panel Survey of Family Dynamics, less than 10 percent of the population attended junior high school in a county that differed from their county of birth in the period after 1968 .

\footnotetext{
${ }^{4}$ In Taiwan, children must be 6 years old on September 1 of year $t$ to enter the first grade in that year and must be 12 years old on September 1 to enter the seventh grade. We have the exact date of birth (day, month, and year) of all individuals in our data. Hence, age in 1968 pertains to age as of September 1. To be specific, an individual born on September 2, 1956 is assigned an age of 11 in 1968, while an individual born on September 1, 1956 is assigned an age of 12. Individuals born between September 2, 1967 and September 1, 1968 are assigned an age of 0 or less than 1 in 1968. Individuals born from September 2, 1968 through December 31, 1968 are excluded from the data.
} 
For cohorts ages 12 and under in 1968, our specific procedure is to interact a dichotomous indicator of each cohort with the county-specific cumulative number of new junior high schools per thousand children ages 12-14 (hereafter termed program intensity) in the year in which the cohort entered junior high school. To be specific, 12 year olds are assigned the program intensity measure in 1968, 11 year olds are assigned the intensity measure in 1969, 10 year olds are assigned the measure in 1970, 9 year olds are assigned the measure in 1971, 8 year olds are assigned the measure in 1972, and those 7 years old and younger are assigned the measure in 1973. Hence, within each county, we exploit variations across cohorts in new junior high school openings to construct an instrument for years of formal schooling completed.

We employ this instrument to estimate the causal effects of mother's or father's schooling on the incidence of low birthweight and mortality of infants born to women in the treatment and control groups or the wives of men in these groups in the period from 1978 through 1999. When the effects of mother's schooling are examined, the control group consists of women between the ages of 13 and 20 in 1968. Since husbands typically are older than their wives, the control group consists of men between the ages of 13 and 25 when the effects of father's schooling are obtained.

Taiwanese authorities planned to allocate more new junior high schools to counties where initial enrollment in junior high schools was low. There is some evidence that this allocation was achieved. The simple correlation coefficient between the cumulative per capita number of new junior high schools in 1973 and the junior high school enrollment rate in 1966 across the 21 counties in Table 1 is -0.27 , and the corresponding correlation between the program intensity variable and the percentage of workers in agriculture (an alternative measure of education needs) 
in 1967 is $0.37 .^{5}$ While these correlation coefficients are not significant at conventional levels, they are based on a small number of observations. Moreover, different magnitudes might emerge in the birth certificate data that we utilize and in the specifications that we employ. For these reasons, we include interactions between cohort indicators and the percentage of workers in agriculture in 1967 and between cohort indicators and the junior high school enrollment rate in 1966 in all regressions.

While the 1968 legislation called for compulsory education through the ninth grade, the percentage of primary school graduates who entered junior high school was only 84 percent in 1973 and did not reach 95 percent until 1978. This was due to lagged responses to the legislation and lack of enforcement. Moreover, while enrollment in junior high school was mandatory as of September 1, 1968, attendance was not compulsory until May 12, 1982 (Tsai 2007a). These factors highlight an identification strategy that takes account of program intensity as well as treatment status.

\section{Empirical Implementation}

\section{A. Data}

Our data collection consists of all birth certificates and infant death certificates for the years 1978 through 1999. There were more than 300,000 births a year in Taiwan during this period. Birth and death certificates are linked through national identification numbers received by each person born in Taiwan. We consider the following outcomes from these data: the probability a low-weight (less than 2,500 grams) birth; the probability of a neonatal death, the probability of a postneonatal death, and the probability of an infant death.

\footnotetext{
${ }^{5}$ The corresponding weighted (by the number of children ages 12-14 in 1967) correlation coefficients are -0.26 and 0.20 , respectively.
} 
Low birthweight has extremely strong positive associations with infant morbidity and mortality. Neonatal deaths pertain to deaths within the 27 days of life, while postneonatal deaths pertain to deaths between the ages of 28 and 364 days. Infant deaths are the sum of those occurring in the neonatal and postneonatal periods. We distinguish between neonatal and postneonatal mortality because their causes are very different. Most neonatal deaths are caused by congenital anomalies, prematurity, and complications of delivery, while most postneonatal deaths are caused by infectious diseases and accidents. Infants who die within the first 27 days of life are excluded when the probability of postneonatal death is the outcome.

In addition to birthweight, birth certificates contain the following information that is relevant for our research: infant's date of birth, mother's date of birth, mother's city or county of birth, father's date of birth, father's city or county of birth, mother's schooling, and father's schooling, Observations with missing values are deleted. Birthweights under 400 grams or over 6,500 grams are treated as missing. These cases are excluded when the probability of low birthweight is the outcome but are included with the three other outcomes. ${ }^{6}$

When we estimate the effects of mother's schooling on infant health, we consider births to women who were between the ages of less than 1 and 20 in 1968 and between the ages of 22 and 45 when they gave birth in the period from 1978 through 1999 . We do not include births to women under the age of 22 because we do not have birth certificates prior to 1978 . The youngest women in the control group were 13 in 1968 and 23 in 1978. When we estimate the effects of father's schooling on infant health, we consider births to the wives of husbands who were between the ages of less than 1 and 20 in 1968 and between the ages of 22 and 50 when

\footnotetext{
${ }^{6}$ Unlike U.S. birth certificates, Taiwanese certificates do not contain such prenatal health inputs and behaviors as month in which prenatal medical care began, number of prenatal care visits, and maternal cigarette smoking and alcohol use during pregnancy. Marital status and parity are available, but births to unmarried women accounted for less than 2 percent of all births in our sample period, and that indicator and parity are potentially endogenous.
} 
their wives gave birth in the years 1978-1999. Recall that age in 1968 pertains to age as of September 1 . We select a wider age range for fathers than for mothers because husbands typically are older than their wives. Father's schooling and mother's schooling are too highly correlated to include both variables in the same regression, especially since the data are aggregated for reasons explained below.

We aggregate the data into mother's or father's county of birth, mother's or father's cohort in 1968, and child's year of birth cells. For mothers, there are 21 counties of birth, 21 cohorts (ages less than 1 through 20 in 1968), and 22 child's years of birth (1978-1999). This gives 9,702 potential cells, but 1,849 have no births. Hence, there are 7,853 observations in the regressions with mother's schooling. For fathers, there are 26 cohorts (ages less than 1 through 25 in 1968), resulting in 12,012 potential cells. Of these, 1,770 have no births, and there are 10,242 observations in the regressions with father's schooling.

We aggregate the data for several reasons. First, aside from parents' schooling, no individual-level variables are employed as regressors. Second and more importantly, ordinary least squares estimates of the effects of schooling on the infant health outcomes that we consider are much bigger in absolute value in the aggregate data than they are in the individual data. In our view the most compelling explanation of this result is that there is random measurement error in the schooling variables, which are obtained from parents. These errors are greatly reduced or eliminated in the aggregate data. In the infant health outcome equations, variations in predicted schooling are based on an instrument that varies only at the county and cohort levels. Hence, it is misleading to compare the IV estimate of the effect of mother's or father's schooling on infant health to the corresponding OLS estimate obtained from the individual-level data. ${ }^{7}$

\footnotetext{
${ }^{7}$ Card $(1999,2001)$ and others point to random measurement error as an explanation of the larger IV than OLS estimates of the effect of schooling on earnings. Our results suggest that the IV coefficient should be compared to
} 


\section{B. Preliminary Investigation of the Effects of the Instrument on Schooling}

We present preliminary results of educational attainment associated with Taiwan's reform in 1968. We summarize the data in three ways: simple differences-in-differences (DD); a regression discontinuity design (RDD); and linear probability models (LPM) of completed schooling. This summary utilizes a pure treatment group-control group methodology adjusted for trends and does not employ the program intensity measure.

The DD, RDD, and LPM are based on the birth certificates and are limited to mothers or fathers who were ages 25 through 34 at birth of the child. They also are based on the Taiwan survey of married women's knowledge, attitudes and practice of family planning and reproductive health, commonly known by acronym KAP. We combine four KAP surveys [KAP V (1980), KAP VI (1986), KAP VII (1992), and KAP VIII (1998)], and we include all women who were 25-34 at the time of the survey. The KAP surveys lack information on birth outcomes and are of limited sample size. Nevertheless, they provide an opportunity to assess the impact of educational reform on completed schooling from a population-based survey of married women.

We begin the analysis with a simple comparison of educational attainment among women and men exposed and unexposed to reform based on birth certificates. The age-period-cohort diagram in Table 2 illustrates how we select the samples of women and men. All children 12 years or less prior to September 1, 1968 were subject to the reform. We contrast the educational attainment of women or men who were 11 and 12 years as of September 1, 1968 to women or

the OLS coefficient obtained at the level of aggregation of the instrument. A second explanation of our results is that there may be spillover effects in the sense that the health outcome of a child depends on the average schooling of parents in his or her area as well as on the schooling of the infant's own parents. 
men who were 14 and 15 years of age in the same year. ${ }^{8}$ However, the economy in Taiwan was growing rapidly during this period and educational attainment would be expected to increase among younger cohorts without reform. To adjust for these trends in educational attainment, we compute differences in completed schooling between women or men who were 9 and 10 years versus women who were 6 and 7 years of age in 1968. This difference is an attempt to estimate the general upward trend in schooling in Taiwan in the years soon after reform. Finally, we limit the sample to women or men who were 25 to 34 years of age at the time of the birth in order to standardize the age at birth within each cohort (see Table 2).

The results from the DDs are shown in Table 3. We show mean levels of schooling for each cohort. Column (1) pertains to women from the birth certificates, column (2) to women from the KAPS and column (3) to men from birth certificates. The standard errors of regression coefficients from which the t-ratios shown in the table are adjusted for clustering by age using Huber's (1967) algorithm in Stata. ${ }^{9}$ The DDs based on birth certificates indicate that schooling among women and men who were 11 and 12 years of age in 1968 increased by 0.38 and 0.59 years, respectively, after reform. The increase for women based in the KAPs is larger, almost a full year of schooling is associated with reform (column 2). Given a mean level of schooling of approximately 9 years for those 11 and 12 in 1968, these estimates suggest that Taiwan's education reform was associated with an increase of between 4 to 10 percent in average schooling.

A second way to summarize changes in education attainment in Taiwan associated with reform is to use a regression discontinuity design (RDD). We include a dichotomous indicator

\footnotetext{
${ }^{8}$ See Table 4 for evidence that it is appropriate to include 13 and 14 year olds in the control group.

${ }^{9}$ The DD, RDD, and LPM regressions employ individual data, but are not subject to the measurement error issue because the only regressors are nonlinear functions of age in 1968. There are 8 clusters in the DD regressions. Tests of significance of regression coefficients employ 7 degrees of freedom, which equals the number of clusters
} 
for the treatment group (those under the age of 13) and a quadratic in age to control for trends in schooling. Standard errors are again adjusted for clustering by age. The RDD measures the difference in completed schooling between the treatment and control groups. However, unlike with the DDs, we include all women and men who were between 0 and 15 years of age in 1968 in order to more accurately fit the trend in educational attainment. Results are displayed in the last row of Table 3. The estimated gains in completed schooling are smaller than those obtained with the DDs, but the relative ranking across samples and gender are the same, and all are statistically significant.

Lastly, we follow Duflo (2001) and present results from a linear probability model (LPM) of the form:

$$
\mathrm{S}_{\mathrm{im}}=\alpha_{0}+\beta_{0} \mathrm{C}_{6-7}+\beta_{1} \mathrm{C}_{9-10}+\beta_{2} \mathrm{C}_{10-11} .
$$

The dependent variable, $S_{i m}$, is 1 if woman " $i$ " has completed at least "m" years of schooling and 0 otherwise. The independent variables are cohort indicators used in the DD for years of schooling completed. We run " $m$ " regressions, one for each year of completed schooling $(\mathrm{m}=3,4, \ldots 16)$ and compute a separate DD for each regression $\left[\beta_{2}-\left(\beta_{0}-\beta_{1}\right)\right]$. The estimated DDs are displayed in Figure 2. There is a sharp rise in those who have completed at least 8 or 9 years of schooling associated with reform. There is evidence that the effects of reform carry over to high school, but they have no effect on post-secondary education. As with the DDs and RDDs, the likelihood of completing at least 8 or 9 years of schooling associated with reform is greater for men than women. Thus, results from the LPM provide evidence that reform affected those who would not have pursued additional schooling. Since there is some evidence that the reform had effects on the probabilities of completing schooling levels beyond junior high school and

minus one (Stata Corporation 2005). Since the age range is less than 1 through 15 in the RDDs, there are 16 clusters in these models. 
since we have not yet incorporated program intensity, we continue to focus on years of formal schooling completed.

The point of these preliminary analyses is to show in a transparent manner that Taiwan's educational reform is associated with a substantial increase in schooling among the expected cohorts and along the expected margins. We also find it reassuring that the increase in schooling is also evident in a population based sample of married women. However, the DD and RDD do not take advantage of the substantial variation in the construction of new schools across counties and over time in Taiwan. Thus, in the next section we provide preliminary results from regressions that exploit variation in program intensity.

C. Preliminary Investigation of the Effects of the Instrument on Schooling: Incorporation of Program Intensity

We now incorporate program intensity into the regression analysis based on the aggregate data. The approach is to represent schooling completed by treatment cohort a $(a=0,1 \ldots, 12)$ in county $\mathrm{j}\left(\mathrm{S}_{\mathrm{aj}}^{\mathrm{t}}\right.$, where the superscript denotes that the cohort is a member of the treatment group) as

$$
\mathrm{S}_{\mathrm{aj}}^{\mathrm{t}}=\alpha_{\mathrm{a}}+\sum_{\mathrm{j}=1}^{20} \phi_{\mathrm{j}} \mathrm{D}_{\mathrm{j}}+\beta_{\mathrm{a}} \mathrm{P}_{\mathrm{aj}}
$$

Here $D_{j}$ is a dummy variable for county $j$ and $P_{a j}$ is the program intensity measure for cohort a in county $\mathrm{j}$ from Table 1 . Recall that it is defined as the county-specific cumulative number of new junior high schools per thousand children ages 12-14 (hereafter termed program intensity) in the year in which the cohort entered junior high school. To be specific, 12 year olds are assigned the program intensity measure in 1968, 11 year olds are assigned the intensity measure in 1969,10 year olds are assigned the measure in 1970, 9 year olds are assigned the measure in 1971, 8 year olds are assigned the measure in 1972, and those 7 years old and younger are assigned the 
measure in 1973. Along the same lines, we represent schooling completed by control cohort a $(a=13,14 \ldots, 20$ for mothers and $a=13,14, \ldots 25$ for fathers $)$ in county $j\left(S_{a j}^{c}\right.$, where the superscript denotes that the cohort is a member of the control group) as

$$
\mathrm{S}_{\mathrm{aj}}^{\mathrm{c}}=\alpha_{\mathrm{a}}+\sum_{\mathrm{j}=1}^{20} \phi_{\mathrm{j}} \mathrm{D}_{\mathrm{j}}
$$

Equation (6) specifies a set of 13 separate equations, one for each cohort in the treatment group. Similarly equation (7) specifies a set of 8 separate equations for mothers and 13 separate equations for fathers, one for each cohort in the control group. Obviously, none of these equations can be estimated. For a given cohort in the treatment group, program intensity is perfectly collinear with the county dummies. Moreover, for a given cohort in either the treatment or control group, the county dummies fully explain schooling.

Estimation is possible by pooling the system contained by equations (6) and (7) with a set of cohort dummies. Consider the pooled model for mothers. It is given by

$$
\mathrm{S}_{\mathrm{aj}}=\alpha_{20}+\sum_{\mathrm{a}=0}^{19}\left(\alpha_{\mathrm{a}}-\alpha_{20}\right) \mathrm{C}_{\mathrm{a}}+\sum_{\mathrm{j}=1}^{20} \phi_{\mathrm{j}} \mathrm{D}_{\mathrm{j}}+\sum_{\mathrm{a}=0}^{12} \beta_{\mathrm{a}} \mathrm{C}_{\mathrm{a}} \mathrm{P}_{\mathrm{aj}}
$$

where $\mathrm{C}_{\mathrm{a}}$ is a dummy variable for cohort a. The cohort dummies capture trends in schooling not associated with reform or program intensity. The county dummies control for cohort-invariant unmeasured factors that vary among counties and may be correlated with schooling and program intensity. The identification assumption is that the county and cohort effects do not interact.

For reasons indicated in Section II, we augment equation (8) with interactions between each of the 13 treatment cohort dummies and the county-specific junior high school enrollment rate in 1966 and between each of these 13 dummies and the county-specific percentage of workers in agriculture in 1967 . That equation assumes that the data are aggregated by cohort and county, but in fact they are aggregated by cohort, county, and year of birth of child. Therefore, 
we include dichotomous indicators for each year of birth from 1978 through 1998 and interactions between these indicators and mother's or father's county of birth. Clearly, we want to take account of year of birth effects when one of the four infant health measures is the outcome. In part, these effects reflect advances in medical technology, changes in the nature of health insurance coverage for prenatal and neonatal care (see Chou, Liu, and Grossman 2005 for details), the legalization of abortion in 1985, and increases in its availability. The interactions allow these developments to have differential impacts over time in different counties. ${ }^{10}$ Given the two-stage least squares methodology, year and county-year interactions must be included in the first stage equation that predicts schooling if they appear in the second stage. In addition, they control for changes in the composition of births over time.

Table 4 contains coefficients of the interactions between cohort dummies in the treatment group and program intensity from estimates of equation (8) for mother's schooling and father's schooling. The regressions are estimated across 7,853 county-cohort-year of birth cells for mother's schooling and across 10,242 cells for father's schooling and are weighted by the square root of the number of births in each cells. The standard errors of regression coefficients from which the t-ratios shown in the table are computed are clustered at the county level. ${ }^{11}$ Recall that 13 and 14 year olds who had previously ended their education after primary school were allowed to return to school as part of the 1968 reform. To examine whether it is appropriate to include them in the control or treatment groups, two regressions are obtained for each outcome. In the first, program intensity as of 1968 is interacted with indicators for each of these two cohorts, and an F-test is performed of the significance of these two coefficients as a

\footnotetext{
${ }^{10}$ The mother's age in 1968 and the year in which she gave birth determine her age at birth. Thus, the cohort and year effects partially reflect the impacts of age at birth. While age at birth could be included in the regressions, we did not do so because it is potentially endogenous.
} 
set. ${ }^{12}$ In the second specification, these two cohort-program intensity interactions are omitted.

For females, there is no evidence that 13 and 14 year olds belong in the treatment group. The two coefficients in question are not significant either separately or as a set and are much smaller than any of the coefficients for the younger cohorts. For males, the two coefficients are significant at the 10 percent level on a one-tail test but not at the 5 percent level. ${ }^{13}$ They are not significant as a set and are smaller than the coefficients for the younger cohorts. Hence, we accept the hypothesis that 13 and 14 year olds should be included in the control group and focus on the second specification.

For females, 12 of the 13 program intensity coefficients are significant at the 10 percent level on a one tail test; 4 are significant at the 5 percent level; and 1 is significant at the 1 percent level. More importantly, the F-ratio associated with the test that the 13 coefficients are significant as a set equals 28.58 . This is much larger than the critical F-ratio of 10 used to assess whether instruments are weak (for example, Staiger and Stock 1997; Cameron and Trivedi 2005). The Stata Corporation (2005) and Scribney (1997) recommend an adjustment to the Fratio when the number of clusters is less than $100{ }^{14}$ Their adjustment results in an F of 11.43,

\footnotetext{
${ }^{11}$ Since there are 21 clusters, t-tests of the significance of regression coefficients assume 20 degrees of freedom.

${ }^{12}$ Given the cluster procedure in Stata, the F-ratio is computed as W/q, where W is the Wald test statistic and q is the number of restrictions (two in the test described in the text). The significance of the F-ratio is based by comparing it to the critical $\mathrm{F}(\mathrm{q}, \mathrm{d})$, where $\mathrm{d}$ is the number of clusters minus one.

${ }^{13} \mathrm{We}$ evaluate the significance of the regression coefficients discussed in this section and the next one with onetailed tests since the alternative hypotheses are (1) the program intensity coefficients are positive when schooling is the outcome; (2) the program intensity coefficients are negative when one of the four negative correlates of infant health is the outcome; and (3) the schooling coefficients are negative when one of the four negative correlates of infant health is the outcome. For readers who prefer two-tailed tests, the critical t-ratios with 20 degrees of freedom are 1.72 at the 10 percent level, 2.09 at the 5 percent level, and 2.84 at the 1 percent level.

${ }^{14}$ Refer to footnote 13. The formula that relates the adjusted $\mathrm{F}\left(\mathrm{F}^{\prime}\right)$ to the unadjusted $\mathrm{F}$ is

$$
\left.F^{\prime}=F[(d-q+1) / d)\right]
$$

In our case $\mathrm{d}=20$ and $\mathrm{q}=13$. Hence $\mathrm{F}^{\prime}=(8 / 20) * 28.58=11.43$
} 
which still exceeds 10. For males, all 13 coefficients are significant at the 10 percent level; 7 are significant at the 5 percent level; and 1 is significant at the 1 percent level. Unadjusted and adjusted F-ratios associated with the test that the 13 coefficients are significant as a set are 16.62 and 6.65 , respectively. Both reject the hypothesis that intensity coefficients are not significant as a set. The latter is somewhat smaller than 10 but does exceed the value of 5, which Cameron and Trivedi (2005) propose as a less strict rule of thumb.

For each gender, there is not much variation in the program intensity coefficients. For females, they range from 0.48 to 0.79 with a mean of 0.61 . For males, the corresponding range is from 0.57 to 1.01 with a mean of 0.92 . Multiplication of the program intensity coefficient for a given cohort by the mean value of program intensity for that cohort yields an estimate of the increase in schooling due to the 1968 compulsory school reform and its aftermath. For females these increase ranges from 0.17 years for those 1 year old in 1968 to 0.07 years for those 12 years old in 1968. The mean gain is 0.11 years. For males, the increases range from 0.22 for those less than 1 year old in 1968 to 0.11 for those 12 years old in that year. The mean gain is 0.16 years. Given mean levels of female and male schooling of 9.53 years and 10.12 years, respectively, these estimates imply that the program raised female schooling by approximately 1.2 percent and raised male schooling by approximately 1.6 percent.

The estimates just presented are smaller than those from the DDs and RDDs. But note that the 13 program coefficients are very similar for each gender. This suggests that there are efficiency and precision gains in restricting these coefficients to be the same. This can be accomplished by fitting a regression of the form

$$
\mathrm{S}_{\mathrm{aj}}=\alpha_{20}+\sum_{\mathrm{a}=0}^{19}\left(\alpha_{\mathrm{a}}-\alpha_{20}\right) \mathrm{C}_{\mathrm{a}}+\sum_{\mathrm{j}=1}^{20} \phi_{\mathrm{j}} \mathrm{D}_{\mathrm{j}}+\beta \sum_{\mathrm{a}=0}^{12} \mathrm{C}_{\mathrm{a}} \mathrm{P}_{\mathrm{aj}} .
$$

For a given treatment cohort 


$$
\sum_{a=0}^{12} \mathrm{C}_{\mathrm{a}} \mathrm{P}_{\mathrm{aj}}=\mathrm{C}_{\mathrm{a}} \mathrm{P}_{\mathrm{aj}} .
$$

Hence equation (9) is equivalent to

$$
\mathrm{S}_{\mathrm{aj}}=\alpha_{20}+\sum_{\mathrm{a}=0}^{19}\left(\alpha_{\mathrm{a}}-\alpha_{20}\right) \mathrm{C}_{\mathrm{a}}+\sum_{\mathrm{j}=1}^{20} \phi_{\mathrm{j}} \mathrm{D}_{\mathrm{j}}+\beta \mathrm{T}_{\mathrm{a}} \mathrm{P}_{\mathrm{aj}}
$$

where $T_{a}$ is a dummy variable that equals one for those between the ages of less than 1 and 12 in 1968 and equals zero otherwise.

In addition to precision and efficiency criteria, equation (10) is appealing because it recognizes that in a fundamental sense there is one instrument for schooling rather than 13. At the same time, it allows for variations in the effect of the program $\left(\beta \mathrm{P}_{\mathrm{aj}}\right)$ on different treatment cohorts. We adopt this specification in obtaining estimates of the reduced form schooling and health equations and the structural health equation in the next section. ${ }^{15}$

\section{Cox's Modified Logistic Specification}

The last issue we address before presenting the full set of results is that of functional form. The infant health outcomes that we investigate are rare events. For example, in the data set for mothers, the percentage of light births is 4.30 percent. The neonatal and infant mortality rates expressed as deaths per thousand live births are 2.32 and 5.89 , respectively. The postneonatal mortality rate expressed as deaths per thousand infants who survive the neonatal period is $3.57 .^{16}$ These figures, which are very similar in the data set for fathers, translate into

\footnotetext{
${ }^{15}$ To be consistent, the junior high school enrollment rate in 1966 and the percentage of workers in agriculture in 1967 are interacted with the single treatment dummy.

${ }^{16}$ Let $\pi_{\mathrm{i}}$ be the infant mortality rate (deaths within the first 364 days of life divided by births), $\pi_{\mathrm{n}}$ be the neonatal mortality rate (deaths within the first 27 days of life divided by births), and $\pi_{\mathrm{p}}$ be the postneonatal mortality rate (deaths between 28 and 364 days of life divided by infants who survive the neonatal period). Then
}

$$
\pi_{\mathrm{i}}=\pi_{\mathrm{n}}+\mathrm{f} \pi_{\mathrm{p}}
$$


probabilities of a light birth, a neonatal death, a postneonatal death, and an infant death of $0.04303,0.00232,0.00357$, and 0.00589 , respectively. Since the outcomes range between 0 and 1 and are uncommon, we apply a logistic transformation to our grouped data. One problem is that a number of cells have no low-weight births or no deaths. Again with reference to the data set for mothers, 8 percent of the 7,853 cells have no low-weight births, 44 percent have no neonatal deaths, 38 percent have no postneonatal deaths, and 28 percent have no infant deaths. ${ }^{17}$

Given the nature of the data, we employ Cox's (1970) modified logistic transformation to the dependent variables in the health outcome equations. Let $Y_{i} \equiv N_{i} / D_{i}$ be one of the four health outcomes in the ith cell. For example, in the case of low birthweight, $\mathrm{N}_{\mathrm{i}}$ is the number of light births and $\mathrm{D}_{\mathrm{i}}$ is the total number of births. Then the dependent variable is

$$
\ln Z_{i}=\ln \frac{Y_{i}+\frac{1}{2 D_{i}}}{1-Y_{i}+\frac{1}{2 D_{i}}}=\ln \frac{N_{i}+0.5}{D_{i}-N_{i}+0.5}
$$

The regression employs a set of weights given by

$$
\mathrm{W}_{\mathrm{i}}=\left[\frac{\mathrm{D}_{\mathrm{i}}\left(\mathrm{N}_{\mathrm{i}}+1\right)\left(\mathrm{D}_{\mathrm{i}}-\mathrm{N}_{\mathrm{i}}+1\right)}{\left(\mathrm{D}_{\mathrm{i}}+1\right)\left(\mathrm{D}_{\mathrm{i}}+2\right)}\right]^{1 / 2} .
$$

We want to make several comments on the procedure just described. First, we have compared the results to those obtained when the cells with the zeros are deleted and a grouped logit with weights given by $\left[D_{i} Y_{i}\left(1-Y_{i}\right)\right]^{1 / 2}$ is fit. They are very similar. Second, the former estimates are not sensitive to weighting by predicted as opposed to actual values of $Y_{\mathrm{i}}$. In the

\footnotetext{
where $\mathrm{f}$ is the ratio of neonatal survivors to total births. Since $\mathrm{f}$ is less than $1, \pi_{\mathrm{i}}$ is less than the sum of $\pi_{\mathrm{n}}$ and $\pi_{\mathrm{p}}$. The ratio in question is, however, so close to 1 that the discrepancy between the infant mortality rate and the sum of the neonatal and postneonatal mortality rates is noticeable only if the rates are expressed with more than five decimal places.

${ }^{17}$ For fathers, 9 percent of the 10,242 cells have no low-weight births, 47 percent have no neonatal deaths, 38 percent have no postneonatal deaths, and 29 percent have no infant deaths.
} 
Cox procedure weights must be based on actual values. Third, our procedure is not subject to Cameron and Trivedi's (2005) criticism that grouped logits should not be obtained when variation in some of the regressors is eliminated by aggregation into cells. In our case schooling is the only right-hand side variable whose variation is reduced by grouping. As we have previously indicated, this is desirable because it reduces measurement error. Finally, there are four sets of weights, one each for low birthweight, neonatal mortality, postneonatal mortality, and infant mortality. Therefore, four reduced form equations for schooling are obtained since the same set of weights is employed in the first and second stages of two-stage least squares estimation.

\section{Results}

Table 5 contains estimates of the effects of educational reform on mother's and father's years of formal schooling completed from the specification given by equation (10). This specification obtains a single program coefficient from the interaction between program intensity and the dichotomous indicator for treatment status. As explained in the previous section, four regressions are estimated for each gender because the weights employed in each of the four health outcome equations differ. For females, all four program coefficients are positive and significant at the 1 percent level. More importantly, the F-ratios associated with the test for weak instruments all exceed the critical value of 10 . Since the structural health equation is exactly identified, these F-ratios simply are given by the square of the corresponding t-ratios. They are 12.74 with the weights for low birthweight, 10.18 with the weights for neonatal mortality, and 13.76 with the weights for postneonatal or infant mortality. ${ }^{18}$

For males, the program coefficients are somewhat smaller than for females. All four are

\footnotetext{
${ }^{18}$ Since there is only one instrument, the unadjusted and adjusted F-ratios defined in footnotes 16 and 17 are the same.
} 
significant at the 10 percent level, but only three are significant at the 5 percent level, and only 1 is significant at the 1 percent level. The F-ratios associated with the test for weak instruments are 8.58 with the weights for low birthweight, 2.76 with the weights for neonatal mortality, 5.15 with the weights for postneonatal mortality, and 5.62 with the weights for infant mortality. All of these fall short of the critical value of 10 , but three of them exceed the less strict rule of thumb of 5 .

For both females and males in the treatment group, the cumulative number of new junior high school openings per thousand children ages 12-14 has a mean of 0.20. Hence for females, the effect of the 1968 school reform legislation on years of completed schooling is 0.26 years in models 1 and 3, 0.21 years in model 2, and 0.25 years in model 4 . For males, the increases are 0.23 years in model $1,0.16$ years in model 2 , and 0.22 years in models 3 and 4 . An average of these effects gives an increase of approximately one-fourth of year for females and approximately one-fifth of a year for males. Put differently, the legislation induced 25 percent of women in the treatment group to attend school for an additional year, while it induced 20 percent of men in the treatment group to gain an additional year of schooling.

The smaller F-ratios for males than for females in the weak instruments test mirror those in Table 4. Both sets of results suggest that program intensity is a better instrument for mother's schooling than for father's schooling. Given these results and the somewhat larger impacts on completed schooling for females, we put more weight on the reduced form and structural infant health equations that contain either mother's program intensity or mother's schooling and discuss them first. These estimates are presented in Table 6 . In each of the four infant health outcome equations, the logit coefficient of mother's program intensity is negative and significant at the 1 percent level (see panel A). A similar comment applies to the coefficients of mother's schooling 
in the structural infant health equations estimated by weighted least squares (WLS, see panel B). These estimates treat mother's schooling as exogenous and thus ignore the possibility that it is correlated with the disturbance term in the equation.

Perhaps the most interesting set of results in the table pertains to the structural infant health equations estimated by weighted two-stage least squares (WTSLS, see panel C). These estimates treat schooling as endogenous and employ the interaction between treatment status and program intensity as an instrument. Although the schooling coefficients have much larger standard errors in the WTSLS regressions, all are negative and all are significant at the 5 percent level. Moreover, the WTSLS and WLS coefficients are similar in magnitude. The ratio of the former coefficient to the latter is 0.86 for low birthweight, 0.75 for neonatal mortality, 1.38 for postneonatal mortality, and 1.31 for infant mortality. Finally, the F-ratio resulting from the $\mathrm{Wu}$ (1973)-Hausman (1978) test suggests the estimates that treat schooling as exogenous are consistent. We want to emphasize that this finding cannot be traced to the use of a weak instrument for schooling.

The corresponding estimates of infant health equations that contain either father's program intensity or father's schooling are given in Table 7. All four logit coefficients of father's program intensity are negative, but only three of the four are significant at the 1 percent level (see panel A). The fourth, which pertains to neonatal mortality, is significant at 10 percent. This differs from the results for mother's program intensity in which all four coefficients are significant at 1 percent. Moreover, the father's coefficients are smaller in absolute value than the corresponding mother's coefficients. The ratio of the former to the latter ranges from 0.59 in the case of neonatal mortality to 0.87 in the case of low birthweight.

When father's schooling is treated as exogenous, all four coefficients are negative, 
significant at the 1 percent level, and similar in magnitude to the corresponding mother's coefficients (see panel B). These coefficients retain their negative signs in WTSL, but only the low- birthweight coefficient is significant at 5 percent (see panel C). This coefficient is joined in significance at the 10 percent level by those in the postneonatal and infant mortality regressions. There is more variability in the ratio of WTSL to WLS coefficients for fathers than for mothers. The former ratio ranges from 0.56 for neonatal mortality to 1.32 for postneonatal mortality. The mother WTSL coefficients are larger in absolute value than the father WTSL coefficients The Wu-Hausman test supports the consistency of estimates that treat schooling as exogenous. Some caution is required here because the instrument for father's schooling does not have an F-ratio in excess of 10 .

To gauge the magnitudes of the effects of mother's or father's schooling on each of the infant health outcomes, we compute the reduction in each adverse outcome associated with the increase in schooling caused by the 1968 school reform legislation. Refer to equation, let $K_{i} \equiv 1 / 2 D_{i}$, let a bar over a variable denote a mean, and let $\gamma$ be the logit coefficient of schooling in one of the four health outcome equations. Then we compute

$$
Y_{1}=\frac{e^{\gamma \Delta S}\left(\bar{Y}+\bar{K} \bar{Y}+\bar{K}+\bar{K}^{2}\right)-\bar{K}+\bar{K} \bar{Y}-\bar{K}^{2}}{e^{\gamma \Delta S}(\bar{Y}+\bar{K})+1-\bar{Y}+\bar{K}} .
$$

In this equation $\Delta \mathrm{S}=\beta \overline{\mathrm{P}}$, where $\beta$ is the regression coefficient of program intensity in the schooling equation and $\overline{\mathrm{P}}$ is the mean of program intensity in the treatment group. The absolute difference between $Y_{1}$ and $\bar{Y}$ shows the reduction in one of the four adverse infant health outcomes associated with an increase in schooling of $\Delta \mathrm{S}$ years.

Table 8 contains the results of the computations just described. For a given parent and a given health outcome, two estimates are shown. The first employs the WLS value of $\gamma$, while the 
second employs the WTSLS value of that coefficient. Our results imply that the WLS value is consistent. Nevertheless, we show both estimates because the Wu-Hausman test may have relatively low power given the loss in efficiency associated with two-stage least squares.

Focusing on the results for mother's schooling, one sees that the percentage of lowbirthweight-births falls by 0.24 percentage points when the WLS coefficient is employed in the computation. This translates into a percentage reduction in the number of light births in a fixed population of births of 5.5 percent. The WTSLS figures are slightly smaller. The percentage of light births falls by 0.20 percentage points or by 4.74 percent. Reductions in mortality range from a decline of 0.20 neonatal deaths per thousand live births to a decline of 0.77 infant deaths per thousand live births. In percentage terms, the smallest decline is an 8.41 percent fall in the number of neonatal deaths. The largest decline is an 18.63 percent reduction in the number of postneonatal deaths. These absolute and percentage reductions in mortality emerge from WTLS.

With one exception, the reductions associated with increases in father's schooling are smaller than those associated with mother's schooling. The exception is the percentage point reduction in the percentage of light births in WLS. Here the reduction for father's schooling exceeds that for mother's schooling by only 0.01 percentage points. Taken together, the results in Tables 6, 7, and 8 suggest that mother's schooling is a more important determinant of infant health outcomes than father's schooling. In one sense this is not a surprising finding given the role of the mother in the prenatal and neonatal periods and the much lower likelihood that mothers work in the postneonatal period. The finding is related to the historical role of the mother as the family member most involved with children. The importance of mother's schooling relative to father's schooling should not, however, be viewed as a foregone conclusion. Historically, fathers have made much larger contributions to family income than mothers, 
especially since they have been more likely to work in the labor market. Since earnings are so dependent on schooling, father's schooling might dominate mother's schooling in infant health outcomes if the schooling effect simply reflected command over real resources. Our results suggest that this is not the case. We are not able to reach a definitive conclusion because collinearity between the two schooling variables, especially when both are treated as endogenous, prevent us from including both of them in the same regression. ${ }^{19}$

\section{Discussion}

Our results suggest that parents' schooling, especially mother's schooling, causes favorable infant health outcomes. In particular, an increase in mother's schooling lowers the probability that an infant will be born light or will die in the neonatal or postneonatal periods. Our results also suggest that schooling can be treated as exogenous in estimating these effects.

The last result may seem puzzling because schooling clearly is an endogenous variable. If one recognizes this a priori, then a literal interpretation of our findings is that the schoolinghealth system is recursive rather than simultaneous and that the disturbance terms in the two equations are not correlated. Lack of simultaneity means that parents ignore the impacts of their schooling on the health of their offspring when they make optimal schooling decisions. Uncorrelated disturbance terms mean that unobserved factors that govern schooling outcomes are not related to unobserved factors that govern infant health outcomes.

This literal interpretation may be too narrow and naive. Parents play an important role in the schooling outcomes of their children and may take account of all potential benefits in allocating resources to their children's schooling. But the infant health benefits associated with

\footnotetext{
${ }^{19}$ See the Appendix for more details.
} 
investments in schooling may be small relative to other benefits in these investments. In this case, a recursive specification may approximate reality.

Even if the recursive specification is correct, the disturbance terms in the two equations may share a common element. Time preference is an obvious candidate, as suggested by Fuchs (1982). In the schooling equation, however, variations in time preference may be small relative to variations in observed determinants of this outcome such as its price. If a minor part of the variation in schooling is due to time preference, the bias introduced by treating it as exogenous will be small.

The endogenous time preference hypothesis proposed by Becker and Mulligan (1997) complicate the situation. If causality runs solely from schooling to time preference, one does not want to control for the latter in estimating the effect of the former on health. Now suppose there is two-way causality between schooling and time preference and that time preference is replaced by its determinants in the health equation. Then the correlation that determines biases is that between schooling and the disturbance term that results from this substitution rather than the correlation between schooling and time preference itself. The former correlation is likely to be smaller than the latter.

An alternative approach to our results is possible. Two-stage least squares estimation results in a loss of efficiency. For example in the infant mortality logit, the standard error of mother's schooling rises by a factor of 12 when it is treated as endogenous. Hence, one may want to interpret $\mathrm{Wu}$-Hausman consistency tests with some caution. If that approach is taken, our two-stage least squares estimates should be stressed. These estimates allow us to conclude that mother's schooling causes favorable infant health outcomes without having to dismiss any of the factors that generate inconsistencies when schooling is treated as exogenous. 
Our findings should be placed in the context of the Taiwan experience. One factor that may make them different from results for the U.S. is that postneonatal deaths accounted for 60 percent of all infant deaths in Taiwan during our sample period. By contrast, they accounted for only 36 percent of all infant deaths in the U.S. Parents may play an important role in preventing or dealing with the infectious diseases and accidents that are the major causes of postneonatal mortality.

A second and related factor is that a large percentage of Taiwanese women and children lacked health insurance prior to the enactment of National Health Insurance in March 1995 (see Chou, Liu, and Grossman 2005 for details). Mother's education may be an especially important factor in postneonatal infant health outcomes in this setting. The larger absolute and percentage impacts of mother's schooling on postneonatal mortality than on neonatal mortality (see Table 8) provide evidence in support of this proposition.

In summary, we have used a natural experiment in Taiwan to answer the question: Do increases in parents' schooling cause better infant health? Our answer to this question is yes. We have presented tentative evidence that mother's schooling is a more important determinant of these outcomes than father's schooling, implying that the mechanism via which schooling operates is not solely an increase in command over real resources. Beyond that we have not investigated the mechanisms via which schooling operates because we lack data on infant health inputs. Studies that examine this issue deserve high priority on an agenda for future research. But caution should be exercised in using the results of these studies to evaluate the causal role of schooling in health outcomes. After all, there is a widespread consensus that increases in schooling cause higher earnings even though there are few studies that identify the mechanisms via which this effect operates. Moreover, suppose that the most important mechanism is one that 
is extremely difficult to measure such as time preference. One would not want to discard evidence that schooling causes health contained in studies such as ours simply because the mechanisms cannot be identified. 


\section{$\underline{\text { Appendix }}$}

\section{A. Birth and Infant Death Certificates}

The main issue in dealing with Taiwanese birth and infant death certificates is that of duplicate infant identifications in the birth certificate files. These duplications resulted in more than one birth being matched to an infant death. Therefore, we spent a considerable amount of time in developing algorithms to circumvent this issue. The final algorithm first eliminated all perfect duplications. These were identified by examining all variables on the birth certificates. Then additional duplications were eliminated based on the following variables: infant's identification number, infant's county of birth, infant's gender, and infant's date of birth. Finally, birth certificates and infant death certificates were merged on the variables just specified.

\section{B. Estimation of New Junior High School Openings}

We obtained estimates of new junior high school openings in each year in the period from 1968 through 1972 by county from a publication of the Ministry of Education of Taiwan entitled Fourth Education Yearbook of the Republic of China, 1974. In many cases we had to visit the web site of a specific school to verify that its opening date in the publication just cited was correct and was not the date on which its construction was authorized. We also excluded from new junior high school openings cases in which the junior high school campus of a combined junior and senior high school in 1967 became independent of the senior high school in 1968. The publication just cited did not contain new junior high school openings by county after 1972. Therefore, for 1973, we obtained a complete list of all junior high schools in Taiwan from Educational Statistics of the Republic of China. We then visited the web site of each school and found its opening date. 


\section{Regressions with Mother's Schooling and Father's Schooling: Problems}

Aggregation of the data by mother's county of birth, father's county of birth, mother's age in 1968, father's age in 1968, and child's year of birth resulted in a large number of cells and a small number of births per cell. Weighted least squares estimates of structural infant health equations similar to those in panel B of Tables 5 and 7 yielded schooling coefficients that were much smaller than those in the tables just mentioned. These regressions contained a single schooling variable. The schooling coefficients were comparable in magnitude to those obtained in the individual data. We concluded that a considerable amount of measurement error remained in the schooling variables after aggregation by mother's and father's characteristics.

Given the result just mentioned, we obtained cell mean values of father's characteristics for the data set aggregated by mother's characteristics. That is, for each cell, we computed the fraction of fathers in each cohort, the fraction born in each county, the mean value of program intensity, and the mean value of schooling. We followed the same procedure with the data set aggregated by father's characteristics. We then fit models similar to those in Tables 5 and 6 or 7 and 8 but with mother's program intensity and father's program intensity in the reduced form and with mother's schooling and father's schooling in the structure. These regressions were plagued by multicollinearity. For example, in the mother data set, the simple correlation coefficient between mother's program intensity and father's program intensity was 0.77 ; the simple correlation coefficient between the actual value of mother's schooling and the actual value of father's schooling was 0.98 ; and the simple correlation between the predicted values of these two variables also was 0.98 . Similar simple correlation coefficients characterized the father data set. These extremely high correlation coefficients made it impossible to include mother's schooling and father's schooling in the same regression. 


\section{$\underline{\text { References }}$}

Adams, S. J. "Educational Attainment and Health: Evidence from a Sample of Older Adults." Education Economics 10: 97-109, 97-109, 2002.

Arendt, J. N. "Does Education Cause Better Health? A Panel Data Analysis Using School Reform for Identification.” Economics of Education Review 24: 149-160, 2005.

Arendt, J. N. "In Sickness and in Health--Till Education Do Us Part: Education Effects on Hospitalization." Economics of Education Review, forthcoming.

Arkes, J. “Does Schooling Improve Adult Health?” Working Paper, RAND Corporation, 2004.

Auster, R., I. Leveson, and D. Sarachek. "The Production of Health, an Exploratory Study." Journal of Human Resources 4: 411-436, 1969.

Becker, G. S., and C. B. Mulligan. "The Endogenous Determination of Time Preference." Quarterly Journal of Economics 112: 729-758, 1997.

Berger, M. C., and J. P. Leigh. "Schooling, Self-Selection, and Health.” Journal of Human Resources 24: 433-455, 1989.

Breierova, L., and E. Duflo. "The Impact of Education on Fertility and Child Mortality: Do Fathers Really Matter Less Than Mothers?" National Bureau of Economic Research Working Paper No. 10513, 2004.

Cameron, A. C., and P. K. Trivedi. Microeconometrics: Methods and Applications. Cambridge, MA: Cambridge University Press, 2005.

Card, D. "The Causal Effect of Education on Earnings." In Handbook of Labor Economics Vol. 3, edited by O. Ashenfelter and D. Card. Amsterdam: North-Holland, Elsevier Science, 18011863, 1999.

Card, D. "Estimating the Return to Schooling: Progress on Some Persistent Econometric Problems." Econometrica 69: 1127-1160, 2001.

Chou, S.-Y., J.-T. Liu, and M. Grossman. "The Impact of National Health Insurance on Birth Outcomes: A Natural Experiment in Taiwan." Presented at the Fifth World Congress of the International Health Economics Association, Barcelona, Spain, July 10-13, 2005.

Cipollone, P., D. Radicchia, and A. Rosolia. "The Effect of Education on Youth Mortality." Working Paper, Bank of Italy, 2007.

Clark, D. E. , and C.-T. Hsieh. "Schooling and Labor Market Impact of the 1968 Nine-Year Education Program in Taiwan." Working Paper, Department of Economics, Princeton University, 2000.

Cox, D. R. The Analysis of Binary Data. London: Methuen and Company Ltd. 1970.

Currie, J. and E. Moretti. "Mother's Education and the Intergenerational Transmission of Human Capital: Evidence from College Openings and Longitudinal Data." Quarterly Journal of Economics 118: 1495-1532, 2003.

Deaton, A. "Policy Implications of the Gradient of Health and Wealth." Health Affairs 21: 1330, 2002. 
de Walque, D. "Does Education Affect Smoking Behavior? Evidence Using the Vietnam Draft as an Instrument for College Education." Journal of Health Economics 26: 877-895, 2007.

Duflo, E. "Schooling and Labor Market Consequences of School Construction in Indonesia: Evidence from an Unusual Policy Experiment." American Economic Review 91: 795-813, 2001.

Fuchs, V. R. "Time Preference and Health: An Exploratory Study." In Economic Aspects of Health, edited by V. R. Fuchs. Chicago: University of Chicago Press, 93-120, 1982.

Grimard, F., and D. Parent. Education and Smoking: Were Vietnam Draft Avoiders also More Likely to Avoid Smoking?" Journal of Health Economics 26: 896-926, 2007.

Grossman, M. "Education and Non-market Outcomes." In Handbook of the Economics of Education Vol. 1, edited by E. Hanushek and F. Welch. Amsterdam: North-Holland, Elsevier Science, 577-633, 2006.

Grossman, M. "The Human Capital Model." In Handbook of Health Economics Vol. 1A, edited by A. J. Culyer and J. P. Newhouse. Amsterdam: North-Holland, Elsevier Science, 347-408, 2000.

Grossman, M., and R. Kaestner. "Effects of Education on Health." In The Social Benefits of Education, edited by J. R. Behrman and N. Stacey. Ann Arbor, Michigan: University of Michigan Press, 69-123, 1997.

Hausman, J. A. "Specification Tests in Econometrics." Econometrica 46: 1251-1271, 1978.

Huber, P. J. "The Behavior of Maximum Likelihood Estimates under Nonstandard Conditions." In Fifth Berkeley Symposium on Mathematical Statistics and Probability. Berkeley, CA: University of California Press, 221-233, 1967.

Kenkel, D., D. Lillard, and A. Mathios. "The Roles of High School Completion and GED Receipt in Smoking and Obesity." Journal of Labor Economics 24: 635-660, 2006.

Leigh, J. P., and R. Dhir. "Schooling and Frailty among Seniors." Economics of Education Review, 16: 45-57, 1997.

Lleras-Muney, A. "The Relationship between Education and Adult Mortality in the United States." Review of Economic Studies 72: 189-221, 2005.

McCrary, J., and H. Royer. "The Effect of Female Education on Fertility and Infant Health: Evidence from School Entry Policies Using Exact Date of Birth." National Bureau of Economic Research Working Paper No. 12329, 2006.

Mincer, J. Schooling, Experience, and Earnings. New York: Columbia University Press for the National Bureau of Economic Research, 1974.

Oreopoulos, P. "Estimating Average and Local Average Treatment Effects of Education when Compulsory Schooling Laws Really Matter." American Economic Review 96: 152-175, 2006.

Sander, W. "Schooling and Quitting Smoking." Review of Economics and Statistics 77: 191199, 1995a.

Sander, W. "Schooling and Smoking. Economics of Education Review 14: 23-33, $1995 \mathrm{~b}$. Scribney, W. "Chi-Squared Test for Models Estimated with Robust Standard Errors." 1997. Available at www.stata.com/support/faqs/stat/chi2.html. 
Spasojevic, J. "Effects of Education on Adult Health in Sweden: Results from a Natural Experiment. Ph.D. Dissertation, City University of New York Graduate Center, 2003.

Spohr, C. A. "Formal Schooling and Workforce Participation in a Rapidly Developing Economy: Evidence from 'Compulsory' Junior High School in Taiwan.” Journal of Development Economics 70: 291-327, 2003.

Staiger, D., and J. A. Stock. "Instrumental Variables Regressions with Weak Instruments." Econometrica 65: 557-586, 1997.

Stata Corporation. Stata Base Reference Manual Vol. 3, R-Z, Release 9. College Station, TX: Stata Press, 2005.

Tsai, W.-J. "Does Educational Expansion Encourage Female Workforce Participation? A Study of the 1968 Reform in Taiwan." Chapter 1 in "Three Essays in Applied Microeconomics."

$\mathrm{Ph} . D$. Dissertation, National Taiwan University, 2007a.

Tsai, W.-J. "Intergenerational Transmissions of Human Capital: Natural Experiment from Compulsory Education Reform in Taiwan. Chapter 2 in "Three Essays in Applied Microeconomics." Ph.D. Dissertation, National Taiwan University, $2007 \mathrm{~b}$.

World Bank. World Development Report 1993: Investing in Health. New York: Oxford University Press, 1993.

Wu, D.-M. "Alternative Tests of Independence between Stochastic Regressors and Disturbances." Econometrica 41: 733-750, 1973. 


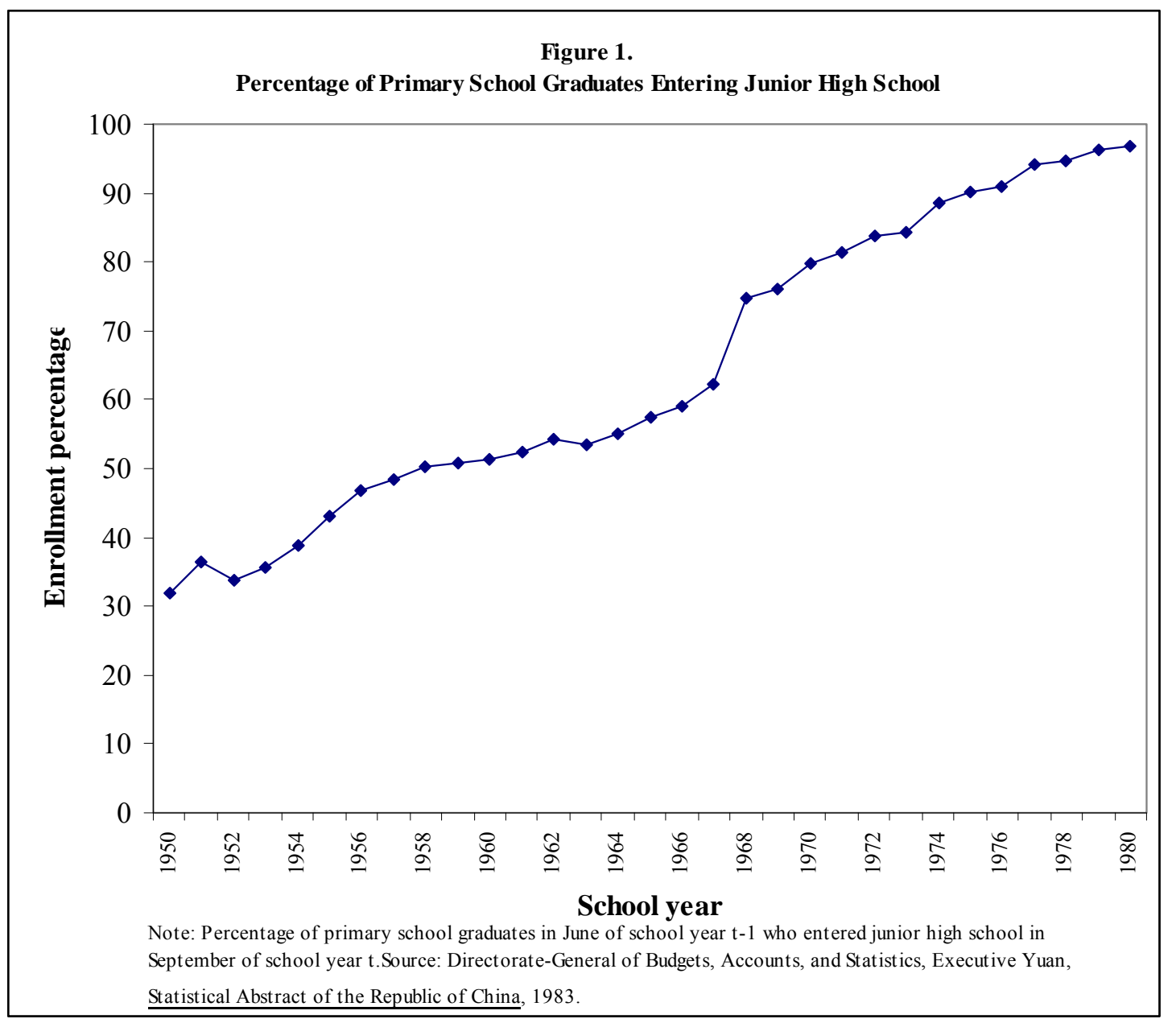


Figure 2.

Probability of Completing at Least "M" Years of Schooling Associated with 1968 Reform in Taiwan

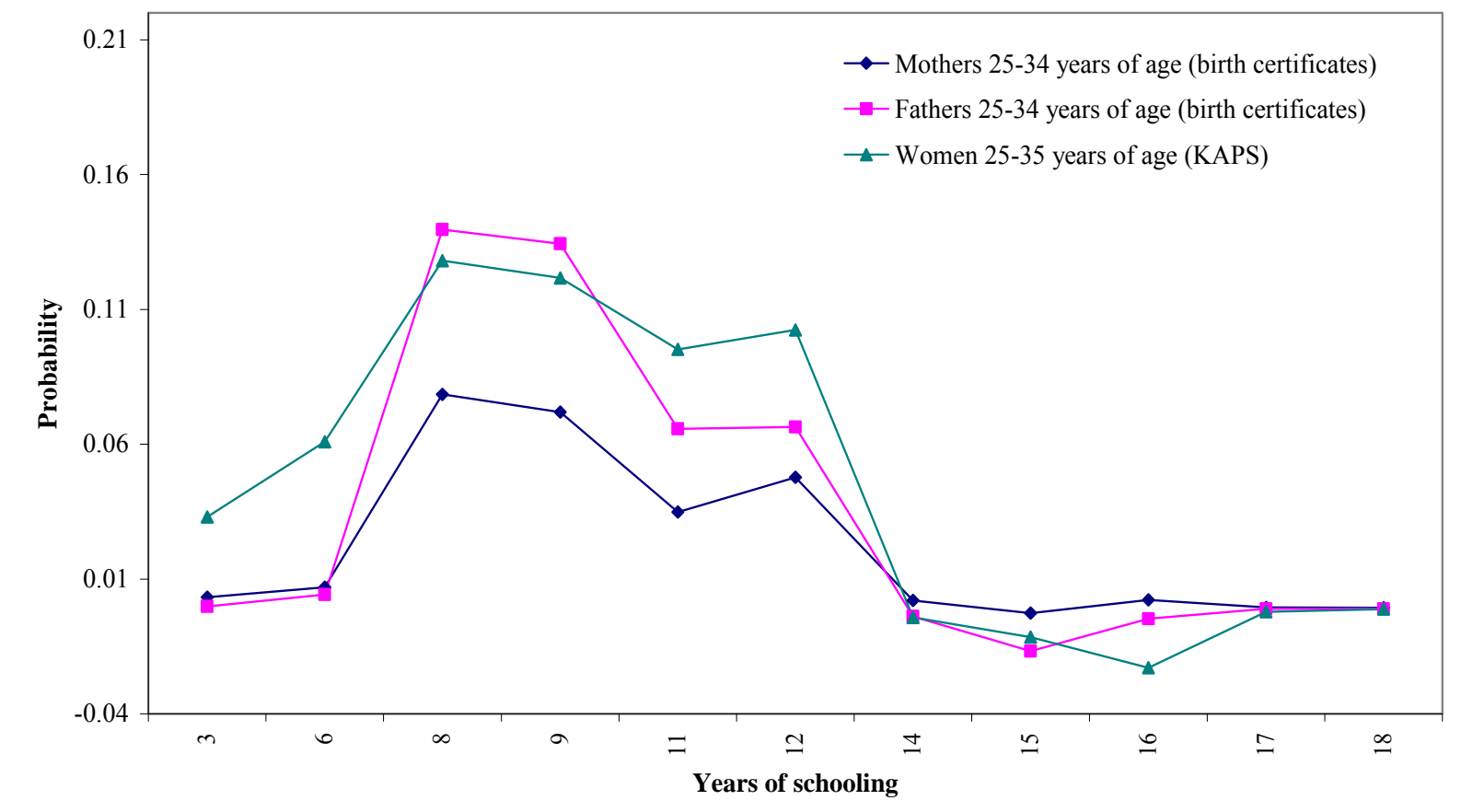


Table 1

Cumulative Number of New Junior High School Openings per Thousand Children Ages 12-14, by School Year and County, 1968-1973

\begin{tabular}{lllllll}
\hline County & $\mathbf{1 9 6 8}$ & $\mathbf{1 9 6 9}$ & $\mathbf{1 9 7 0}$ & $\mathbf{1 9 7 1}$ & $\mathbf{1 9 7 2}$ & $\mathbf{1 9 7 3}$ \\
\hline Taipei City & 0.188 & 0.222 & 0.223 & 0.217 & 0.211 & 0.214 \\
Taichung City & 0.124 & 0.150 & 0.234 & 0.227 & 0.218 & 0.210 \\
Keelung City & 0.162 & 0.156 & 0.153 & 0.152 & 0.150 & 0.150 \\
Tainan City & 0.086 & 0.111 & 0.136 & 0.134 & 0.133 & 0.132 \\
Kaohsiung City & 0.018 & 0.052 & 0.081 & 0.078 & 0.075 & 0.101 \\
Taipei County & 0.135 & 0.186 & 0.189 & 0.254 & 0.214 & 0.204 \\
Ilan County & 0.062 & 0.153 & 0.211 & 0.240 & 0.265 & 0.266 \\
Taoyuan County & 0.100 & 0.134 & 0.130 & 0.144 & 0.191 & 0.182 \\
Chaiyi County & 0.070 & 0.125 & 0.167 & 0.168 & 0.183 & 0.200 \\
Hsinchu County & 0.045 & 0.133 & 0.154 & 0.174 & 0.193 & 0.190 \\
Miaoli County & 0.119 & 0.164 & 0.185 & 0.184 & 0.182 & 0.181 \\
Taichung County & 0.220 & 0.219 & 0.234 & 0.251 & 0.249 & 0.245 \\
Nantou County & 0.166 & 0.164 & 0.258 & 0.330 & 0.401 & 0.402 \\
Changhua County & 0.024 & 0.035 & 0.047 & 0.059 & 0.071 & 0.071 \\
Yunlin County & 0.106 & 0.106 & 0.152 & 0.169 & 0.200 & 0.200 \\
Tainan County & 0.229 & 0.228 & 0.228 & 0.228 & 0.255 & 0.257 \\
Kaohsiung County & 0.016 & 0.046 & 0.061 & 0.075 & 0.133 & 0.130 \\
Pingtung County & 0.195 & 0.193 & 0.222 & 0.221 & 0.220 & 0.219 \\
Hualien County & 0.385 & 0.410 & 0.408 & 0.408 & 0.408 & 0.408 \\
Taitung County & 0.424 & 0.540 & 0.578 & 0.579 & 0.578 & 0.578 \\
Penghu County & 0.529 & 0.516 & 0.708 & 0.803 & 0.904 & 0.911 \\
Country as a whole & $\mathbf{0 . 1 3 6}$ & $\mathbf{0 . 1 6 4}$ & $\mathbf{0 . 1 8 8}$ & $\mathbf{0 . 2 0 1}$ & $\mathbf{0 . 2 1 2}$ & $\mathbf{0 . 2 1 2}$ \\
\hline & & & & & & \\
& & & & & \\
\end{tabular}

Note: Denominator pertains to children ages 12-14 in a given year. The figure for the country as a whole is a weighted average of the figures for each county where the set of weights is the county-specific number of children 12-14. Sources: Ministry of Education, Fourth Education Yearbook of the Republic of China, 1974 and web sites of selected schools for the number of new junior high schools, 1968-1972; the web site of each individual school for 1973; and Directorate-General of Budgets, Accounts, and Statistics, Executive Yuan, Statistical Abstract of the Republic of China, 1983 for the population ages 12-14 in 1968-1973. 
Table 2

Age-Period-Cohort Table of Births to Women in Taiwan 1978-1996

\begin{tabular}{|c|c|c|c|c|c|c|c|c|c|c|c|c|c|c|c|c|c|c|c|c|}
\hline & & \multicolumn{19}{|c|}{ Year of delivery: } \\
\hline & & 78 & 79 & 80 & 81 & 82 & 83 & 84 & 85 & 86 & 87 & 88 & 89 & 90 & 91 & 92 & 93 & 94 & 95 & 96 \\
\hline \multirow{21}{*}{ 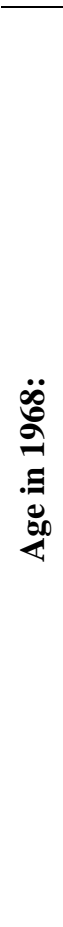 } & 0 & 10 & 11 & 12 & 13 & 14 & 15 & 16 & 17 & 18 & 19 & 20 & 21 & 22 & 23 & 24 & 25 & 26 & 27 & 28 \\
\hline & 1 & 11 & 12 & 13 & 14 & 15 & 16 & 17 & 18 & 19 & 20 & 21 & 22 & 23 & 24 & 25 & 26 & 27 & 28 & 29 \\
\hline & 2 & 12 & 13 & 14 & 15 & 16 & 17 & 18 & 19 & 20 & 21 & 22 & 23 & 24 & 25 & 26 & 27 & 28 & 29 & 30 \\
\hline & 3 & 13 & 14 & 15 & 16 & 17 & 18 & 19 & 20 & 21 & 22 & 23 & 24 & 25 & 26 & 27 & 28 & 29 & 30 & 31 \\
\hline & 4 & 14 & 15 & 16 & 17 & 18 & 19 & 20 & 21 & 22 & 23 & 24 & 25 & 26 & 27 & 28 & 29 & 30 & 31 & 32 \\
\hline & 5 & 15 & 16 & 17 & 18 & 19 & 20 & 21 & 22 & 23 & 24 & 25 & 26 & 27 & 28 & 29 & 30 & 31 & 32 & 33 \\
\hline & 6 & 16 & 17 & 18 & 19 & 20 & 21 & 22 & 23 & 24 & 25 & 26 & 27 & 28 & 29 & 30 & 31 & 32 & 33 & 34 \\
\hline & 7 & 17 & 18 & 19 & 20 & 21 & 22 & 23 & 24 & 25 & 26 & 27 & 28 & 29 & 30 & 31 & 32 & 33 & 34 & 35 \\
\hline & 8 & 18 & 19 & 20 & 21 & 22 & 23 & 24 & 25 & 26 & 27 & 28 & 29 & 30 & 31 & 32 & 33 & 34 & 35 & 36 \\
\hline & 9 & 19 & 20 & 21 & 22 & 23 & 24 & 25 & 26 & 27 & 28 & 29 & 30 & 31 & 32 & 33 & 34 & 35 & 36 & 37 \\
\hline & 10 & 20 & 21 & 22 & 23 & 24 & 25 & 26 & 27 & 28 & 29 & 30 & 31 & 32 & 33 & 34 & 35 & 36 & 37 & 38 \\
\hline & 11 & 21 & 22 & 23 & 24 & 25 & 26 & 27 & 28 & 29 & 30 & 31 & 32 & 33 & 34 & 35 & 36 & 37 & 38 & 39 \\
\hline & 12 & 22 & 23 & 24 & 25 & 26 & 27 & 28 & 29 & 30 & 31 & 32 & 33 & 34 & 35 & 36 & 37 & 38 & 39 & 40 \\
\hline & 13 & 23 & 24 & 25 & 26 & 27 & 28 & 29 & 30 & 31 & 32 & 33 & 34 & 35 & 36 & 37 & 38 & 39 & 40 & 41 \\
\hline & 14 & 24 & 25 & 26 & 27 & 28 & 29 & 30 & 31 & 32 & 33 & 34 & 35 & 36 & 37 & 38 & 39 & 40 & 41 & 42 \\
\hline & 15 & 25 & 26 & 27 & 28 & 29 & 30 & 31 & 32 & 33 & 34 & 35 & 36 & 37 & 38 & 39 & 40 & 41 & 42 & 43 \\
\hline & 16 & 26 & 27 & 28 & 29 & 30 & 31 & 32 & 33 & 34 & 35 & 36 & 37 & 38 & 39 & 40 & 41 & 42 & 43 & 44 \\
\hline & 17 & 27 & 28 & 29 & 30 & 31 & 32 & 33 & 34 & 35 & 36 & 37 & 38 & 39 & 40 & 41 & 42 & 43 & 44 & 45 \\
\hline & 18 & 28 & 29 & 30 & 31 & 32 & 33 & 34 & 35 & 36 & 37 & 38 & 39 & 40 & 41 & 42 & 43 & 44 & 45 & 46 \\
\hline & 19 & 29 & 30 & 31 & 32 & 33 & 34 & 35 & 36 & 37 & 38 & 39 & 40 & 41 & 42 & 43 & 44 & 45 & 46 & 47 \\
\hline & 20 & 30 & 31 & 32 & 33 & 34 & 35 & 36 & 37 & 38 & 39 & 40 & 41 & 42 & 43 & 44 & 45 & 46 & 47 & 48 \\
\hline
\end{tabular}

Figures are the age of women by year of birth and age in 1968. Women who were 14 and 15 years of age in 1968 were unaffected by reform. Women ages 11 to 12 were the first cohorts exposed to reform. Differences in educational attainment between women 11 and 12 versus 14 and 15 in 1968 captures changes due to reform as well as on-going trends in educational attainment in Taiwan. To difference out growth in educational attainment due to general development, we use the differences in completed schooling between women who were 6 and 7 years of age in 1968 and women who were 9 and 10. Thus, the difference-in-differences is ((S11_12)-(S14_15))-((S6_7)(S9_10)) where Sa is the educational attainment of women who were "a" years of age in 1968. 
Table 3

Cohort Differences in Educational Attainment by Gender and Source: Taiwanese Women and Men 25-34 Years of Age at Time of Birth or Survey ${ }^{\mathrm{a}}$

(Dependent Variable: Years of Completed Schooling)

\begin{tabular}{|c|c|c|c|}
\hline & \multicolumn{2}{|c|}{ Women } & \multirow{2}{*}{$\begin{array}{c}\text { Men } \\
\text { Birth certificates }\end{array}$} \\
\hline & Birth certificates & KAPS & \\
\hline \multicolumn{4}{|l|}{ Age in 1968: } \\
\hline a. 6-7 years & 10.42 & 9.84 & 10.80 \\
\hline b. $9-10$ years & 9.84 & 9.26 & 10.52 \\
\hline c. $11-12$ years & 9.36 & 8.89 & 10.24 \\
\hline d. $14-15$ years & 8.41 & 7.38 & 9.38 \\
\hline \multicolumn{4}{|l|}{ Difference-in-differences: } \\
\hline Rows (c-d) - (a-b) & $\begin{array}{l}0.3838^{* *} \\
(2.14)\end{array}$ & $\begin{array}{l}0.9212 * * * \\
(4.41)\end{array}$ & $\begin{array}{l}0.5944^{* * *} \\
(4.52)\end{array}$ \\
\hline Sample Size & $1,631,788$ & 4,467 & $2,158,871$ \\
\hline Regression discontinuity & $\begin{array}{l}0.1469^{* *} \\
(2.30)\end{array}$ & $\begin{array}{l}0.6337 * * * \\
(3.57)\end{array}$ & $\begin{array}{l}0.2806^{* * *} \\
(4.60)\end{array}$ \\
\hline Sample size & $3,370,393$ & 8,489 & $4,036,886$ \\
\hline
\end{tabular}

${ }^{\text {a }}$ T-ratios, reported in parentheses, are computed from standard errors that adjust for clustering by age in 1968.

${ }^{\mathrm{b}}$ Estimate of $\mathrm{a}_{1}$ from the regression $\mathrm{Si}=\alpha_{0}+\alpha_{1}$ Treat $+\alpha_{2}$ Age $68+\alpha_{3}(\text { Age } 68)^{2}$, where $\mathrm{Si}$ is years of complete schooling and Treat is 1 if age in $1968<13$ and zero otherwise. The RDD includes all women who were 0 to 15 years of age in 1968. The KAP RDD includes women from KAPS V -VIII.

*** Significant at the 1 percent level (one-tailed test). $* *$ Significant at the 5 percent level (one-tailed test).

* Significant at the 10 percent level (one-tailed test). 
Table 4

Effects of Educational Reform on Parents' Years of Formal Schooling Completed ${ }^{\mathrm{a}}$

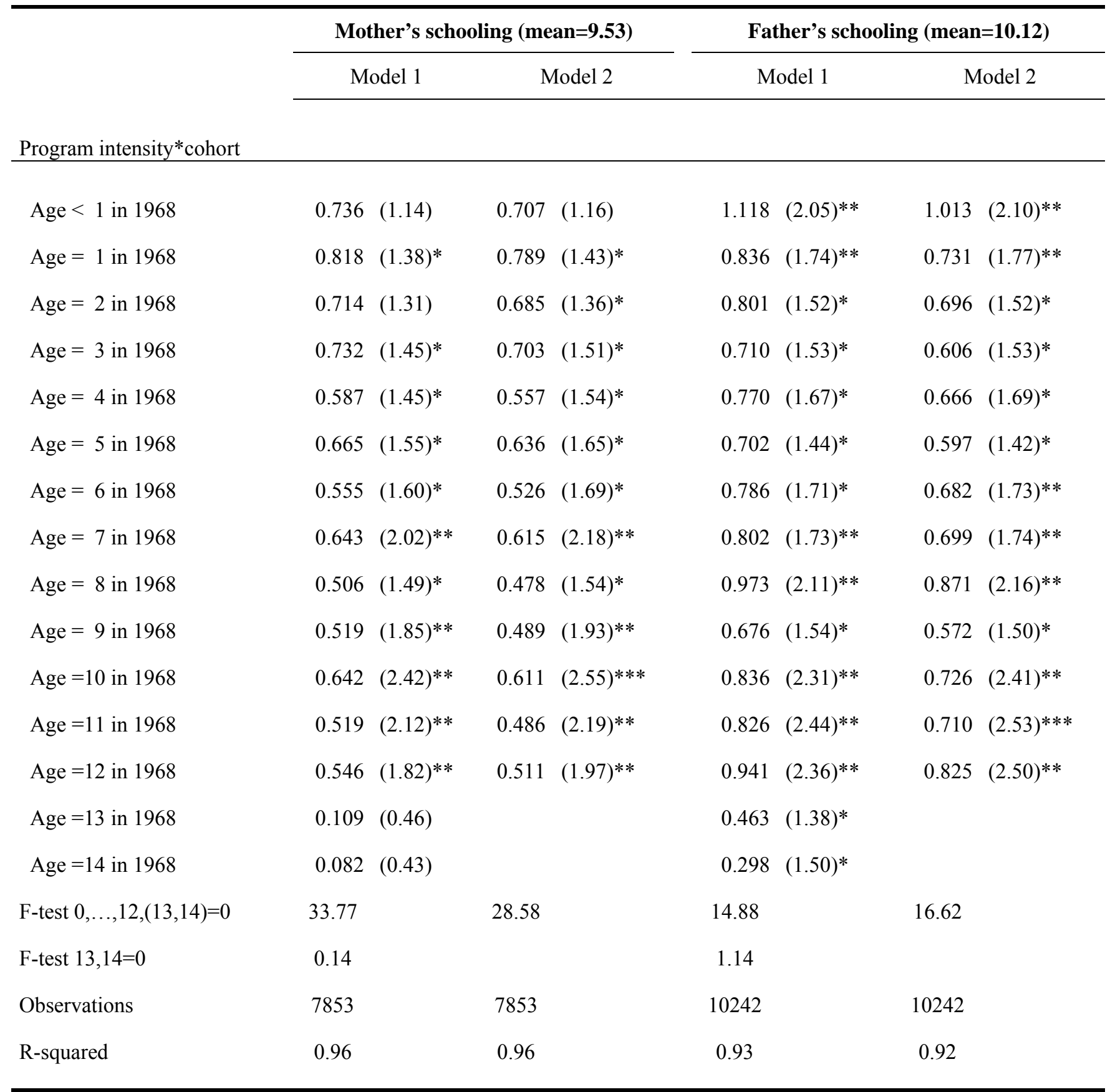

${ }^{\mathrm{a}} \mathrm{T}$-ratios, reported in parentheses, are computed from standard errors that adjust for clustering at the county level. All regressions include 20 cohort dummies, 20 county dummies, 21 year of birth of child dummies, interactions between each of the treatment cohort dummies and the county-specific junior high school enrollment rate in 1966 and between each of the treatment cohort dummies and the percentage of workers in agriculture in 1967, and interactions between the county and year of birth of child dummies.

***Significant at the 1 percent level (one-tailed test). **Significant at the 5 percent level (one-tailed test). *Significant at the 10 percent level (one-tailed test). 
Table 5

\section{Effects of Educational Reform on Parents' Years of Formal Schooling Completed, Single Program Intensity Measure ${ }^{a}$}

\begin{tabular}{|c|c|c|c|c|c|c|c|c|}
\hline \multirow[b]{3}{*}{$\begin{array}{l}\text { Treatment*program } \\
\text { intensity }(\text { mean }=0.20)^{b}\end{array}$} & \multicolumn{4}{|c|}{ Mother's schooling } & \multicolumn{4}{|c|}{ Father's schooling } \\
\hline & Model 1 & Model 2 & Model 3 & Model 4 & Model 1 & Model 2 & Model 3 & Model 4 \\
\hline & $\begin{array}{l}1.288^{* * *} \\
(3.57)\end{array}$ & $\begin{array}{l}1.045^{* * *} \\
(3.19)\end{array}$ & $\begin{array}{l}1.302 * * * \\
(3.71)\end{array}$ & $\begin{array}{l}1.240^{* * *} \\
(3.71)\end{array}$ & $\begin{array}{l}1.143^{* * *} \\
(2.93)\end{array}$ & $\begin{array}{c}0.805^{*} \\
(1.66)\end{array}$ & $\begin{array}{l}1.087 * * \\
(2.27)\end{array}$ & $\begin{array}{l}1.094 * * \\
(2.37)\end{array}$ \\
\hline $\begin{array}{l}\text { R-squared } \\
\text { Observations }\end{array}$ & $\begin{array}{r}0.926 \\
7853\end{array}$ & $\begin{array}{r}0.844 \\
7853\end{array}$ & $\begin{array}{r}0.856 \\
7853\end{array}$ & $\begin{array}{r}0.882 \\
7853\end{array}$ & $\begin{array}{r}0.889 \\
10242\end{array}$ & $\begin{array}{r}0.800 \\
10242\end{array}$ & $\begin{array}{r}0.812 \\
10242\end{array}$ & $\begin{array}{r}0.838 \\
10242\end{array}$ \\
\hline
\end{tabular}

${ }^{a}$ Each of the four models employs a different set of weights. Model 1 uses the weights in the Cox modified logistic equation for low birth weight. Model 2 uses the weights in the equation for neonatal mortality, model 3 uses the weights in the equation for post-neonatal mortality, and model 4 uses the weights in the equation for infant mortality. See equation (12) for more details. T-ratios, reported in parentheses, are computed from standard errors that adjust for clustering at the county level. All regressions include 20 cohort dummies, 20 county dummies, 21 year of birth of child dummies, interactions between the treatment dummy and the county-specific junior high school enrollment rate in 1966 and between the treatment dummy and the percentage of workers in agriculture in 1967, and interactions between the county and year of birth of child dummies.

${ }^{b}$ The mean shown is the mean value of program intensity in the treatment group. The percentage of births in this group is equal to 75 percent for mothers and 62 percent for fathers.

***Significant at the 1 percent level (one-tailed test). ${ }^{* *}$ Significant at the 5 percent level (one-tailed test). $*$ Significant at the 10 percent level (one-tailed test). 
Table 6

Effects of Program Intensity and Mother's Schooling on Infant Health ${ }^{\text {a }}$

\begin{tabular}{|c|c|c|c|c|}
\hline & $\begin{array}{c}\text { Low } \\
\text { birthweight }\end{array}$ & $\begin{array}{l}\text { Neonatal } \\
\text { mortality }\end{array}$ & $\begin{array}{l}\text { Postneonatal } \\
\text { mortality }\end{array}$ & $\begin{array}{c}\text { Infant } \\
\text { mortality }\end{array}$ \\
\hline \multicolumn{5}{|c|}{ Panel A - Reduced Form Infant Health Cox Modified Logit Regressions, Weighted Least Squares } \\
\hline $\begin{array}{l}\text { Treatment*program } \\
\text { intensity }\end{array}$ & $\begin{array}{l}-0.249^{* * *} \\
(-2.81)\end{array}$ & $\begin{array}{l}-0.333 * * * \\
(-3.35)\end{array}$ & $\begin{array}{l}-0.835^{* * * *} \\
(-5.49)\end{array}$ & $\begin{array}{l}-0.626^{* * * *} \\
(-5.65)\end{array}$ \\
\hline R-squared & 0.445 & 0.499 & 0.333 & 0.365 \\
\hline Mean*100 (or 1000) & 4.30 & 2.32 & 3.57 & 5.89 \\
\hline \multicolumn{5}{|c|}{ Panel B - Structural Infant Health Cox Modified Logit Regressions, Weighted Least Squares } \\
\hline Mother's schooling & $\begin{array}{l}-0.226^{* * * *} \\
(-7.48)\end{array}$ & $\begin{array}{l}-0.426 * * * \\
(-22.99)\end{array}$ & $\begin{array}{l}-0.463^{* * *} \\
(-23.69)\end{array}$ & $\begin{array}{l}-0.386 * * * \\
(-22.04)\end{array}$ \\
\hline R-squared & 0.534 & 0.571 & 0.453 & 0.463 \\
\hline \multicolumn{5}{|c|}{ Panel C - Structural Infant Health Cox Modified Logit Regressions, Weighted Two-Stage Least Squares } \\
\hline Mother's schooling & $\begin{array}{l}-0.194^{* *} \\
(-2.36)\end{array}$ & $\begin{array}{l}-0.318^{* *} \\
(-2.01)\end{array}$ & $\begin{array}{l}-0.641^{* *} \\
(-2.49)\end{array}$ & $\begin{array}{l}-0.505^{* *} \\
(-2.45)\end{array}$ \\
\hline R-squared & 0.532 & 0.566 & 0.435 & 0.454 \\
\hline Wu-Hausman F-ratio & 0.23 & 0.32 & 0.69 & 0.46 \\
\hline
\end{tabular}

${ }^{\text {a }}$ Sample size is 7,853 in all regressions. Weights are given by equation (12). T-ratios, reported in parentheses, are computed from standard errors that adjust for clustering at the county level. All regressions include 20 cohort dummies, 20 county dummies, 21 year of birth of child dummies, interactions between the treatment dummy and the county-specific junior high school enrollment rate in 1966 and between the treatment dummy and the percentage of workers in agriculture in 1967, and interactions between the county and year of birth of child dummies. All means except for the postneonatal mortality rate are weighted by the cell-specific number of births. The mean of the latter variable is weighted by the cell-specific number of infants who survive the neonatal period. For low birthweight, the mean is the percentage of light births. For neonatal and infant mortality, the means are deaths per thousand live births. For neonatal mortality, the mean is deaths per thousand survivors of the neonatal period.

***Significant at the 1 percent level (one-tailed test). **Significant at the 5 percent level (one-tailed test). * Significant at the 10 percent level (one-tailed test). 
Table 7

Effects of Program Intensity and Father's Schooling on Infant Health ${ }^{\mathrm{a}}$

\begin{tabular}{|c|c|c|c|c|}
\hline & $\begin{array}{c}\text { Low } \\
\text { birthweight }\end{array}$ & $\begin{array}{l}\text { Neonatal } \\
\text { mortality }\end{array}$ & $\begin{array}{l}\text { Postneonatal } \\
\text { mortality }\end{array}$ & $\begin{array}{c}\text { Infant } \\
\text { mortality }\end{array}$ \\
\hline \multicolumn{5}{|c|}{ Panel A - Reduced Form Infant Health Cox Modified Logit Regressions, Weighted Least Squares } \\
\hline $\begin{array}{l}\text { Treatment*program } \\
\text { intensity }\end{array}$ & $\begin{array}{l}-0.216^{* * *} \\
(-3.60)\end{array}$ & $\begin{array}{l}-0.196^{*} \\
(-1.43)\end{array}$ & $\begin{array}{l}-0.634^{* * *} \\
(-5.42)\end{array}$ & $\begin{array}{l}-0.469 * * * \\
(-4.95)\end{array}$ \\
\hline R-squared & 0.374 & 0.461 & 0.353 & 0.371 \\
\hline Mean $^{*} 100$ (or 1000) & 4.45 & 2.34 & 3.63 & 5.97 \\
\hline
\end{tabular}

Panel B - Structural Infant Health Cox Modified Logit Regressions, Weighted Least Squares
Father's schooling
$-0.253^{* * *}$
$-0.434 * * *$
$-0.442 * * *$
$(-23.13)$
$-0.369 * * *$
$(-9.48)$
$(-21.87)$
0.443
$(-21.06)$
R-squared
0.483
0.526
0.450

Panel C - Structural Infant Health Cox Modified Logit Regressions, Weighted Two-Stage Least Squares
Father's schooling
$-0.189 * *$
$-0.243$
$-0.584 *$
$-0.429^{*}$
$(-2.47)$
$(-0.89)$
$(-1.64)$
$(-1.71)$
R-squared
0.476
0.514
0.434
0.448
Wu-Hausman F-ratio
0.53
0.25
0.23
0.07

\begin{abstract}
aSample size is 10242 in all regressions. Weights are given by equation (12). T-ratios, reported in parentheses, are computed from standard errors that adjust for clustering at the county level. All regressions include 20 cohort dummies, 20 county dummies, 21 year of birth of child dummies, interactions between the treatment dummy and the county-specific junior high school enrollment rate in 1966 and between the treatment dummy and the percentage of workers in agriculture in 1967, and interactions between the county and year of birth of child dummies. All means except for the postneonatal mortality rate are weighted by the cell-specific number of births. The mean of the latter variable is weighted by the cell-specific number of infants who survive the neonatal period. For low birth weight, the mean is the percentage of light births. For neonatal and infant mortality, the means are deaths per thousand live births. For neonatal mortality, the mean is deaths per thousand survivors of the neonatal period.

${ }^{* * *}$ Significant at the 1 percent level (one-tailed test). ${ }^{* *}$ Significant at the 5 percent level (one-tailed test). "Significant at the 10 percent level (one-tailed test).
\end{abstract}


Table 8

Reductions in Low Birthweight and Mortality Due to Increases in Schooling ${ }^{\mathrm{a}}$

\begin{tabular}{|c|c|c|c|c|}
\hline & \multicolumn{2}{|c|}{ Mother's schooling } & \multicolumn{2}{|c|}{ Father's schooling } \\
\hline & $\begin{array}{c}\text { Weighted } \\
\text { least } \\
\text { squares }\end{array}$ & $\begin{array}{c}\text { Weighted } \\
\text { two-stage } \\
\text { least } \\
\text { squares }\end{array}$ & $\begin{array}{c}\text { Weighted } \\
\text { least } \\
\text { squares }\end{array}$ & $\begin{array}{c}\text { Weighted } \\
\text { two-stage } \\
\text { least } \\
\text { squares }\end{array}$ \\
\hline \multicolumn{5}{|l|}{ Outcome } \\
\hline \multicolumn{5}{|l|}{ Low birthweight } \\
\hline Percentage point reduction & 0.237 & 0.204 & 0.246 & 0.185 \\
\hline Percentage reduction in number of light births & 5.512 & 4.744 & 5.528 & 4.157 \\
\hline \multicolumn{5}{|l|}{ Neonatal mortality } \\
\hline Reduction in number of deaths per thousand live births & 0.258 & 0.195 & 0.211 & 0.120 \\
\hline Percentage reduction in number of deaths & 11.121 & 8.405 & 9.017 & 5.128 \\
\hline \multicolumn{5}{|l|}{$\underline{\text { Postneonatal mortality }}$} \\
\hline $\begin{array}{l}\text { Reduction in number of deaths per thousand neonatal } \\
\text { survivors }\end{array}$ & 0.492 & 0.665 & 0.404 & 0.526 \\
\hline Percentage reduction in number of deaths & 13.782 & 18.627 & 11.129 & 14.490 \\
\hline \multicolumn{5}{|l|}{ Infant mortality } \\
\hline Reduction in number of deaths per thousand live births & 0.600 & 0.774 & 0.521 & 0.602 \\
\hline Percentage reduction in number of deaths & 10.187 & 13.141 & 8.727 & 10.084 \\
\hline
\end{tabular}

${ }^{\text {a }}$ Reduction in outcome due to increase in schooling computed by multiplying the coefficient of program intensity in the schooling regression by the mean value of intensity in the treatment group. Percentage reduction assumes no change in the denominator of the relevant outcome. 